\title{
Unraveling the interaction between FcRn and albumin: opportunities for design of albumin-based therapeutics
}

\author{
Kine Marita Knudsen Sand ${ }^{1,2}$, Malin Bern ${ }^{1,2}$, Jeannette Nilsen ${ }^{2,3}$, Hanna Theodora Noordzij ${ }^{1,2}$, \\ Inger Sandlie ${ }^{1,2}$ and Jan Terje Andersen ${ }^{2 *}$
}

${ }^{1}$ Department of Biosciences, Centre for Immune Regulation (CIR), University of Oslo, Oslo, Norway

${ }^{2}$ Department of Immunology, Centre for Immune Regulation (CIR), Oslo University Hospital Rikshospitalet, Oslo, Norway

${ }^{3}$ Institute of Clinical Medicine, University of Oslo, Oslo, Norway

\section{Edited by:}

Swapan K. Ghosh, Indiana State University, USA

Reviewed by:

Peter Timmerman, Pepscan

Therapeutics B.V., Netherlands

So-Yon Lim, Harvard Medical School, USA

Swapan K. Ghosh, Indiana State

University, USA

*Correspondence:

Jan Terje Andersen, Oslo University Hospital Rikshospitalet, Department of Immunology, Sognsvannveien 20, 0027 Oslo, Norway

e-mail: j.t.andersen@medsin.uio.no
The neonatal $F c$ receptor ( $F C R n$ ) was first found to be responsible for transporting antibodies of the immunoglobulin $\mathrm{G}(\mathrm{lgG})$ class from the mother to the fetus or neonate as well as for protecting $\mathrm{lgG}$ from intracellular catabolism. However, it has now become apparent that the same receptor also binds albumin and plays a fundamental role in homeostatic regulation of both IgG and albumin, as FcRn is expressed in many different cell types and organs at diverse body sites. Thus, to gain a complete understanding of the biological function of each ligand, and also their distribution in the body, an in-depth characterization of how FcRn binds and regulates the transport of both ligands is necessary. Importantly, such knowledge is also relevant when developing new drugs, as IgG and albumin are increasingly utilized in therapy. This review discusses our current structural and biological understanding of the relationship between FcRn and its ligands, with a particular focus on albumin and design of albumin-based therapeutics.

Keywords: albumin, FcRn, albumin-based therapeutics, IgG, half-life, recycling, transcytosis

\section{INTRODUCTION}

Albumin and immunoglobulin G (IgG) are the two most abundant circulating proteins in the bloodstream, and account for an incredible $80-90 \%$ of the total protein pool. In addition, both share an extraordinary long serum half-life, which in humans amount to $19-21$ days (1-3). While $\operatorname{IgG}$ is solely produced by $\mathrm{B}$ and plasma cells in response to foreign substances, such as pathogens, and is absolutely fundamental for protection against infections, albumin is produced by hepatocytes of the liver and acts as a multi-carrier of a plethora of insoluble and hydrophobic endogenous and exogenous ligands, such as ions, fatty acids, amino acids, and waste products as well as a range of biomedical drugs. In addition, albumin maintains the osmotic blood pressure, is an important antioxidant, and possesses enzymatic properties (4-6).

Despite their completely unrelated structures and biological roles, IgG and albumin share two common and unique features; extended serum half-life and an inverse relationship between serum concentrations and half-life (1-3). These characteristics were initially proposed to be caused by the presence of specific saturable receptor-mediated mechanisms that would protect the proteins from intracellular degradation $(7,8)$. And indeed, it

Abbreviations: $\beta_{2} \mathrm{~m}, \beta_{2}$-microglobulin; AP-2, adaptor protein 2; ABD, albuminbinding domain; BBB, blood-brain-barrier; DCs, dendritic cells; DARPin, designed ankyrin repeat protein; ER, endoplasmic reticulum; FcRn, neonatal Fc receptor; GLP-1, glucagon-like peptide-1; gp, glycoprotein; HC, heavy chain; HER2, human epidermal growth factor receptor 2; IgG, immunoglobulin $\mathrm{G}$; Ii, invariant chain; MHC, major histocompatibility complex; scFv, single-chain variable fragment; TGF, transforming growth factor; TNF, tumor necrosis factor. later became apparent that a broadly expressed cellular receptor, then named the neonatal $\mathrm{Fc}$ receptor $(\mathrm{FcRn})$, does exist and is responsible for salvaging both IgG and albumin from cellular catabolism via strictly $\mathrm{pH}$-dependent recycling and transcytosis pathways. Thus, FcRn plays a key role in homeostatic regulation of these unrelated soluble proteins, securing a broad biodistribution throughout the body of both molecules (9-13).

Due to its well-recognized serum stability and longevity, albumin has been utilized as a carrier for drugs for a long time, either by direct genetic fusion or conjugation, or by non-covalent association of the drug to albumin (14-16). However, during the development of these strategies, the importance of the FcRn-dependent mechanisms for drug pharmacokinetics and pharmacodynamics was not really taken into account, as they were established before the FcRn-albumin relationship was appreciated. Now, care must be taken that the FcRn interaction is not disrupted when albuminbased therapeutics are designed and evaluated. In addition, we have shown that there are large differences in cross-species binding characteristics of human albumin to mouse and rat FcRn that compromise preclinical in vivo evaluations in rodents $(17,18)$. Thus, the pharmacokinetics and pharmacodynamics of a numerous human albumin-based therapeutics may have to be reassessed, and their FcRn binding ability and transport properties at different body sites taken into account. Furthermore, unmasking the molecular interaction of FcRn with albumin has given rise to new classes of engineered albumin variants with altered FcRn binding and transport capacities. Last, but not least, FcRn is well known to mediate transport of IgG across cellular barriers such as polarized epithelial cells covering mucosal surfaces and the placenta (19-24), which have been successfully utilized as gateways for oral, 
nasal, pulmonary, and in utero delivery of IgG-based therapeutics and vaccines (25-32). Whether albumin can be efficiently shuttled by FcRn via these pathways has not yet been fully addressed and needs to be explored, as such routes may be attractive for delivery of albumin-based therapeutics. In this review, we describe the current molecular and cellular understanding of FcRn and its relationship with its ligands with a particular focus on albumin biology and design of albumin-based therapeutics.

\section{THE HISTORY OF FcRn}

F.W. Rogers Brambell (1901-1970) was the first to postulate the presence of a cellular receptor responsible for active prenatal transport of IgG from the mother to the fetus across the yolk sac in rabbits and across the intestine of neonatal rats $(7,33)$. This was based on experiments done in his own laboratory as well as work done by others, which showed that maternal IgG derived from mother's milk was absorbed from the gut lumen of neonatal rats for up to 18-21 days post birth before the transport rapidly ceased (34). Also, using in vitro intestinal cell assays, it was shown that the transport was highly selective for the IgG isotype and solely dependent on the constant Fc part (35). Based on these observations, Brambell proposed that a single cellular receptor was the key player in mediating transcytosis of IgG over these cellular barriers (7).

Furthermore, Fahey and Robinson demonstrated that IgG was eliminated from the blood circulation in a concentrationdependent manner, as injection of high doses of IgG in mice greatly accelerated the clearance of endogenous IgG, while excess amounts of IgA, IgM, or serum albumin did not (36). Again, the process was fully dependent on Fc. Brambell recognized the resemblance between this work and his own studies, and proposed that a common receptor was responsible for transepithelial and materno-fetal transport, as well as for serum half-life regulation $(7,37)$.

During the 1970s, it was shown that transport of IgG across the intestinal epithelium of the neonatal rat was strictly $\mathrm{pH}$ dependent, as IgG uptake from the mother's milk for delivery to the offspring would only happen at acidic intestinal $\mathrm{pH}$ and not at physiological $\mathrm{pH}$ (38). Almost 10 years later, the receptor in question was identified in tissue from the neonatal rodent gut as a heterodimeric protein consisting of 40-46 and $12 \mathrm{kDa}$ subunits (39). This was followed up by cloning of the corresponding genes, which revealed that the $12 \mathrm{kDa}$ subunit was $\beta_{2}$-microglobulin $\left(\beta_{2} \mathrm{~m}\right)$ while the larger subunit was a heavy chain (HC) related to the major histocompatibility complex (MHC) class I (40). The discovery inspired its name FcRn.

As a parallel to postnatal transport across the neonatal intestine and the prenatal transport of IgG across the yolk sac of rabbits, a human ortholog of FcRn was cloned from syncytiotrophoblasts of the human placenta by Story and colleagues (41), and shown to direct transcytosis of mothers IgG to the fetus during the third trimester of pregnancy (24). In all cases, FcRn-mediated transcytosis ensures transfer of passive immunity to the fetus and the newborn. However, FcRn function is not restricted to neonatal life, as a large body of evidence has shown that it is expressed in a range of cell types in all species studied throughout life (20, 21, 23, 30, 42-53).
In contrast to the well characterized FcRn-IgG relationship, an explanation for the long half-life of albumin was missing for decades. Brambell did only briefly touch upon albumin, but did not discuss its catabolic rate (54). Instead, during the 1960s, Schultze and Heremans postulated that the proposed mechanism for IgG protection from degradation could also explain the correlation between the half-life and concentration-dependent catabolic rate of albumin (8). This was based on studies of the relative catabolic rates of IgG and albumin in patients suffering from agammaglobulinemia and analbuminemia. The work was largely ignored until Anderson and co-workers reported that FcRn binds albumin (11). The interaction was identified by chance when bovine albumin was co-eluted with recombinant soluble human FcRn from an IgG affinity column $(11,55)$. Like the FcRn-IgG interaction, the FcRn-albumin interaction is remarkably $\mathrm{pH}$ dependent (11, $56,57)$. Whereas it was already known that mice, which do not express a functional FcRn, catabolize IgG more rapidly than normal mice $(9,10,58)$, the same rapid catabolic rate was now shown also for albumin (11).

\section{THE ARCHITECTURE OF FcRn}

The neonatal Fc receptor is a transmembrane heterodimeric protein with a structure similar to that of classical and non-classical MHC class I molecules (40). Specifically, it consists of a HC with three extracellular domains ( $\alpha 1, \alpha 2$, and $\alpha 3)$, followed by a transmembrane part and a cytoplasmic tail. The soluble subunit $\beta_{2} \mathrm{~m}$, which is common for almost all MHC class I molecules, is non-covalently paired with the FcRn HC. An overview of the crystal structures of truncated rat and human FcRn is shown in Figures 1A-C.

Inspections of solved crystal structures of soluble truncated recombinant forms of rat and human FcRn have revealed that the extracellular part of the HC has a membrane proximal $\alpha 3$-domain, followed by an amino-terminal $\alpha 1-\alpha 2$ platform that is made up of eight antiparallel $\beta$-strands with two $\alpha$-helices on top (59-65). Further, $\beta_{2} \mathrm{~m}$ associates with the HC by making contacts with the $\alpha 3$-domain, located below the $\alpha 1-\alpha 2$ platform. Proper folding of the heterodimer in the endoplasmic reticulum (ER) is facilitated by Erp57 and calnexin, and has been shown to be a prerequisite for exit from the ER, and subsequent $\mathrm{pH}$-dependent binding to the ligands (66-68).

In contrast to classical MHC class I molecules that present peptides bound in a groove located between the two $\alpha$-helices on top of the $\alpha 1-\alpha 2$ platform, the corresponding groove is occluded in FcRn $(60,62)$. Instead, FcRn has evolved to bind IgG and albumin at separate binding sites on opposite sides of the $\alpha 1$ and $\alpha 2$ domains (57, 64, 69, 70) (Figure 1A). Furthermore, the human HC contains only one putative N-glycosylation site (N102) compared with four sites in the mouse and rat ectodomains (N87, N104, N128, and N225) $(40,59)$ (Figures 1A,B), and the differential glycosylation pattern of human and rat FcRn has been linked to different sorting and distribution in polarized cells (71). The differences in the glycosylation pattern results in molecular weights of 51 and $45 \mathrm{kDa}$ for the mouse and human $\mathrm{HC}$, respectively.

Crystal structures of human FcRn have been solved at both acidic and basic pH (59-61), as well as in complex with both ligands $(64,69,72)$, which show that there are few structural main 

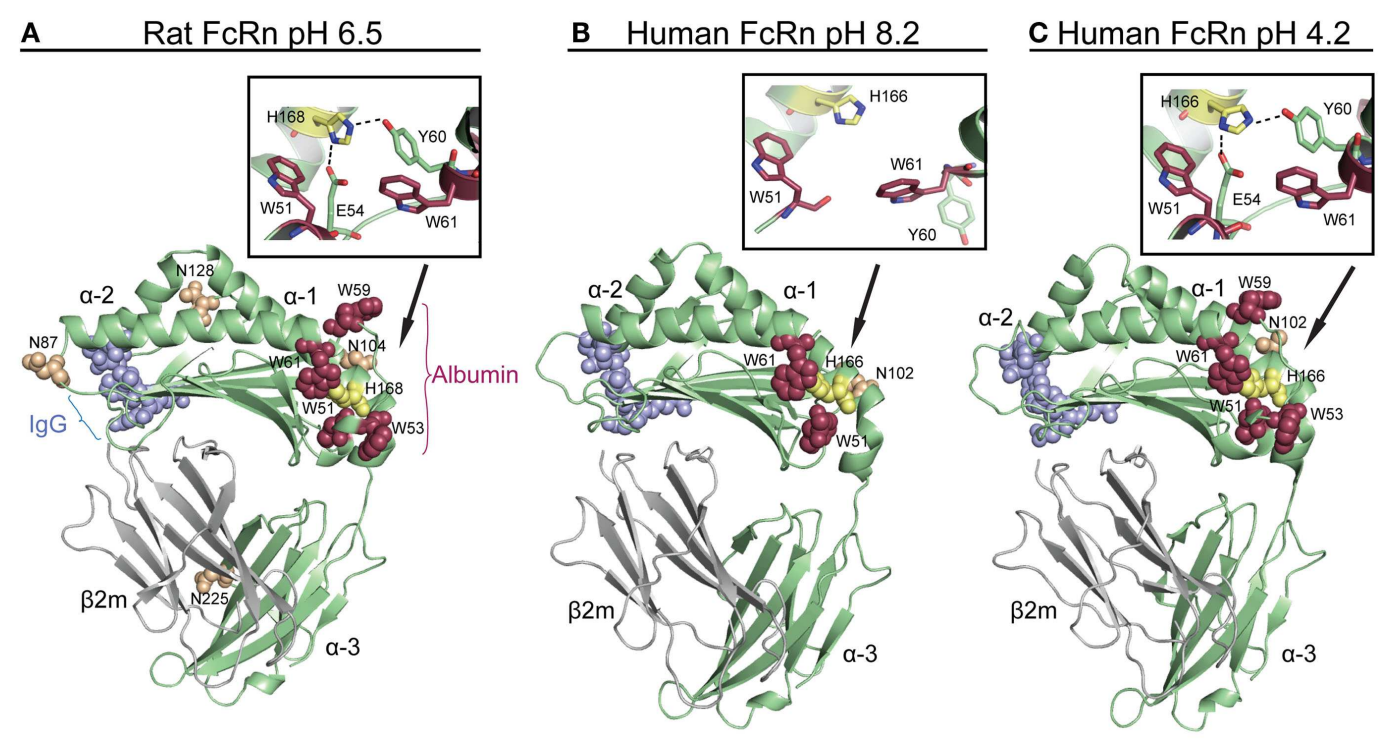

D FcRn cytoplasmic tail

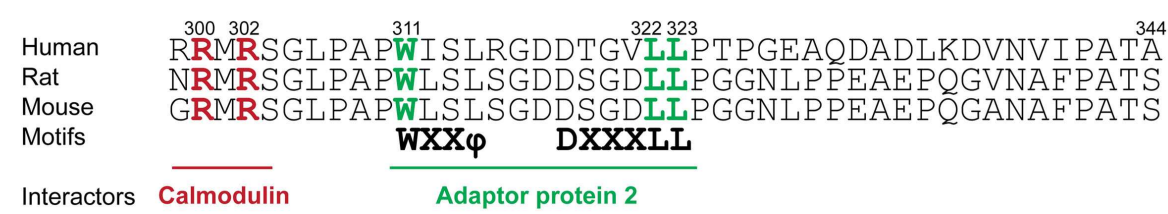

FIGURE 1 | Crystallographic illustrations of rat and human FcRn. Crystal structures of truncated (A) rat FcRn solved at $\mathrm{pH}$ 6.5, (B) human FcRn solved at $\mathrm{pH} 8.2$, and (C) pH 4.2. The $\mathrm{FcRn} \mathrm{HC}$ is shown in green and the $\beta 2 \mathrm{~m}$ subunit in gray $(\mathbf{A}-\mathbf{C})$. The three domains of $F_{C} R n$ are denoted as $\alpha 1, \alpha 2$, and $\alpha 3$. The key amino acid residues involved in binding to $\lg \mathrm{G}$ are shown as blue spheres (L112, E115, E116, W131, P132, and E133, human numbering), while the residues central for albumin binding (W51, W53, W59, and W61) are shown as red spheres. The loop containing the tryptophans is $\mathrm{pH}$ dependently regulated by $\mathrm{H} 166$ ( $\mathrm{H} 168$ in rat) within the a2-domain (yellow spheres, human numbering). The close-ups show how H166 (H168 in rat) stabilizes the loop of amino acid residues corresponding to residues $51-61$ of the $\alpha 1$-domain by forming charged interactions with $\mathrm{E} 54$ and $\mathrm{Y} 60$ at acidic $\mathrm{pH}$. These interactions are not seen in the crystal structure solved at basic $\mathrm{pH}$, which results in an unstructured loop (B). The four putative $\mathrm{N}$-glycosylation sites of rat FcRn are shown in orange spheres (N87, 104, 128, and 225), while only one $\mathrm{N}$-glycosylation site is found in human FcRn (N102). (D) An amino acid sequence alignment of the cytoplasmic tail of FcRn from human, rat, and mouse. The tryptophan and the di-leucine based sorting motifs that interact with the adaptor protein 2 are highlighted in green. Amino acid residues required for calmodulin binding are marked in red (human numbering). The figures were made using PyMol, with the following PDB files; Rat FcRn pH 6.5: 3FRU (59), human FcRn pH 8.2 1EXU (60), human FcRn pH 4.2: 3MIB (61). chain alterations in FcRn as a function of $\mathrm{pH}$, except for a loop within the $\alpha 1$-domain that is only solved at acidic $\mathrm{pH}(60,61)$ (Figures 1B,C). This loop has been shown to be important for binding of albumin (discussed below). Binding of both ligands is strictly $\mathrm{pH}$ dependent, with strong binding at acidic $\mathrm{pH}$ that becomes progressively weaker near neutral $\mathrm{pH}$, suggesting that protonation of histidine residues, which is the only amino acid that changes charge between $\mathrm{pH} 5.5$ and 7.4, is responsible for intra-molecular interactions or direct engagement with ligands.

The cytoplasmic tail of the HC contains conserved sorting motifs that are important for trafficking of the receptor, including di-leucine (L322/L323) and tryptophan (W311) motifs (73). An overview of the stretch of amino acids corresponding to the cytoplasmic tails of mouse, rat, and human FcRn HCs is highlighted in Figure 1D. The tryptophan motif has been demonstrated to interact with the $\mu$ subunit of adaptor protein-2 (AP-2) while the di-leucine motif interacts with the $\sigma$ and $\gamma$ subunits of AP-2 (74). These motifs play a role in rapid endocytosis of the receptor from the plasma membrane into endosomes, and basolateral targeting in polarized rat cells. However, as there are cross-species differences in polarized expression of FcRn in human and rodent cell lines (74-79), additional differences such as the variations in glycosylation patterns may play a role in trafficking of the receptor. Indeed, a study by Kuo and colleagues show that the difference in polarized expression between rat and human FcRn may at least partly be explained by the three additional N-glycosylation sites found in rats (71).

Another motif in the cytoplasmic tail that is conserved among species is a calmodulin binding sequence encompassing R300 and R302 (Figure 1D). Targeting of the motif by mutagenesis resulted in altered transport and decreased stability of the receptor (80). As binding of calmodulin to FcRn is highly regulated by the flux of calcium, it may be a way to modulate endosomal FcRn sorting. In addition, as calmodulin will mask a putative amphipathic $\alpha$-helix in the cytoplasmic tail of FcRn, which for other proteins has been shown to be inserted into the cell membrane and induce or sense curvature, it may add another level of regulation of cellular sorting of the receptor $(80,81)$. 


\section{THE STRUCTURE OF ALBUMIN}

Albumin is exclusively synthesized and secreted into the bloodstream by liver hepatocytes to a concentration of $40 \mathrm{mg} / \mathrm{ml}$ in both mouse and man (4). It is a highly soluble and stable protein that is non-glycosylated and has a molecule weight of $66.5 \mathrm{kDa}$. X-ray crystallographic structures of human albumin has revealed that it is a heart-shaped molecule consisting of a single polypeptide of 585 amino acids with 17 pairs of disulfide bridges and 1 free cysteine (C34) (82-84). An illustration of the crystal structure of human albumin is shown in Figure 2. Albumin consists of $67 \% \alpha$-helices and no $\beta$-sheets, and folds into three homologous domains named DI, DII, and DIII, where each is divided into A and B subdomains (DIA, DIB, DIIA, DIIB, DIIIA, and DIIIB) (85). The domains are connected via long flexible loops.

\section{THE FcRn-ALBUMIN INTERACTION}

When Chaudhury and colleagues co-eluted bovine albumin with soluble human FcRn from a human IgG-coupled column (11), this indicated that both ligands could bind the receptor simultaneously

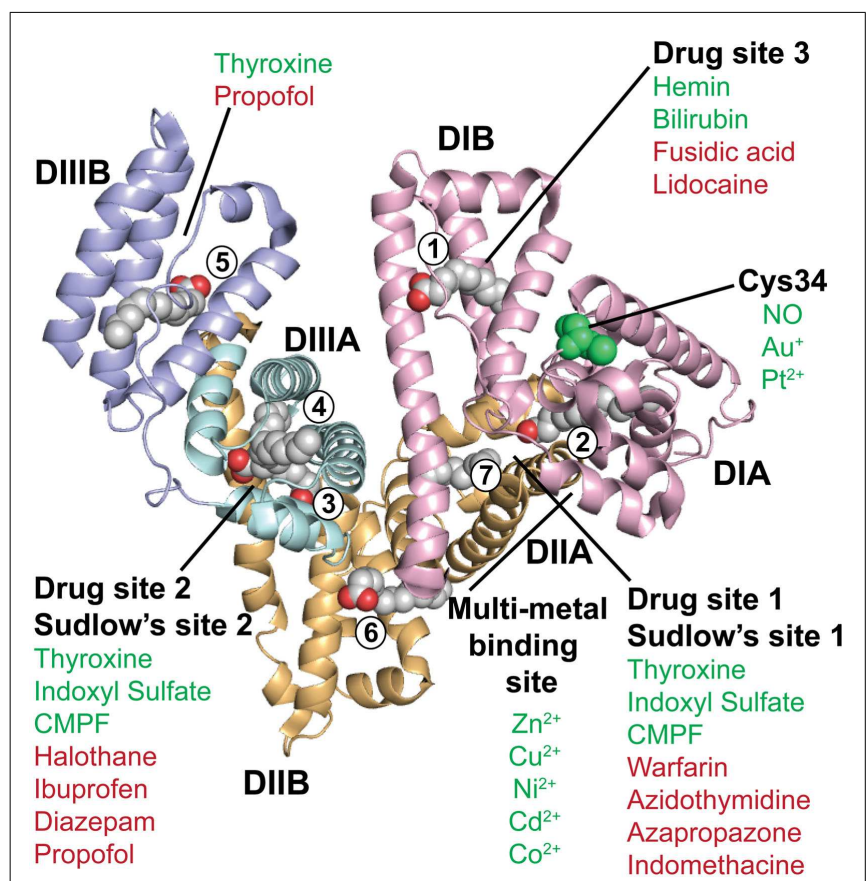

FIGURE 2 | The crystal structure of human albumin. The illustration shows the crystal structure of human albumin solved in the presence of saturating amounts of palmitic acid. The $\alpha$-helical structures of the three domains (DI, DII, and DIII) are divided into subdomains (A and B) as indicated. DI (pink) contains the fatty acid binding site 1 , the free cysteine (C34), and drug binding site 3 . Fatty acid site 2 is located at the interface between DI and DII. The metal binding site is located between subdomain DIA and DIIA. DII (orange) contains the drug binding site 1 (Sudlow's site 1) as well as fatty acid sites 6 and 7. DIII (blue) contains fatty acid binding sites 3 and 4 , the drug binding site 2 (Sudlow's site 2) in DIIIA, and the fatty acid biding site 5 in DIIIB. Examples of the binding sites for endogenous and exogenous ligands for which crystal structures have been solved are listed in green and red, respectively, as reviewed in Ref. (86). The figure was designed using PyMol and the crystal structure data of human albumin solved in the presence of palmitic acid with the PDB file 1E7H (87). CMPF, carboxy-4-methyl-5-propyl-2-furanpropionic acid; NO, nitric oxide. as a ternary complex. Subsequently, in vitro interaction analyses demonstrated this indeed to be the case. Initial mapping of the albumin binding site on human FcRn showed that a fully conserved H166, within the $\alpha 2$-domain of the human FcRn HC, was crucial for binding (56). An explanation for this finding was given upon scrutiny of two crystal structures of human FcRn, one of which was solved at $\mathrm{pH} 4.2$, while the other was solved at $\mathrm{pH} 8.2$ $(60,61)$. An overview of these two crystal structures are shown in Figures 1B,C. A comparison of the two structures revealed that a loop surrounding H166 within the a1-domain was only defined in the structure solved at acidic $\mathrm{pH}$ (61), and not in the structure solved at basic $\mathrm{pH}(60)$. This suggested that the configuration of the loop is $\mathrm{pH}$ sensitive and stabilized at acidic $\mathrm{pH}$ when $\mathrm{H} 166$ is protonated and able to form hydrogen bonds with E54 and Y60 (70) Figures 1A-C shows close-ups of the structural areas surrounding $\mathrm{H} 166$ and the $\mathrm{pH}$ sensitive loop of human and rat FcRn. The importance of these stabilizing interactions was confirmed by mutating E54 to a glutamine, which resulted in low detectable binding of albumin (70). Furthermore, the loop contains four conserved hydrophobic residues; W51, W53, W59, and W61, which are partially or fully surface-exposed (Figures 1B,C). Targeted mutagenesis of these tryptophan residues has demonstrated their fundamental role in binding of albumin, as swapping to alanine residues considerably reduced or abolished binding (72, 88). This means that the interaction is not only $\mathrm{pH}$ dependent but also hydrophobic in nature. In line with this is a previous report showing that the interaction has a large positive change in entropy, indicative of a hydrophobic character (57). The findings strongly support that $\mathrm{H} 166$ has a key regulatory role in stabilizing the loop with the cluster of tryptophan residues that directly take part in binding of albumin.

The principal binding site for FcRn on albumin was first shown to be located within the C-terminal DIII, as removal of this domain eliminated binding of albumin $(70,89)$. Then, targeting three fully conserved histidine residues within DIII of human albumin (H464, H510, and H535) by site-directed mutagenesis revealed that all are crucial for binding (70). In addition, mutating a lysine in position $500(\mathrm{~K} 500 \mathrm{~A})$, located within an extended loop that connects the two subdomains of DIII, was shown to reduce binding to FcRn by more than 30 -fold (70). Furthermore, when recombinant variants of the three human albumin single domains were tested for binding to FcRn, DIII was the only domain that showed detectable binding, although with a more than 10 -fold weaker affinity than full-length albumin (70). Despite limited structural knowledge, a docking model of the human FcRn-human albumin complex was built, where in addition to DIII, two exposed loops within the $\mathrm{N}$-terminal DI were shown to be in proximity to the receptor (70).

In agreement with these predictions, two recently published cocrystal structures of human FcRn in complex with human albumin confirmed the contributions from both DI and DIII, while DII does not take direct part in the interaction $(69,72)$. One of the co-crystal structures shows wild-type albumin, and the Fc part of IgG in complex with FcRn (69), and an illustration of the ternary complex is given in Figure 3. The other co-crystal shows an engineered human albumin variant (HSA13) comprising four amino acid substitutions (V418M, T420A, E505G, and V547A) (72). The latter was 


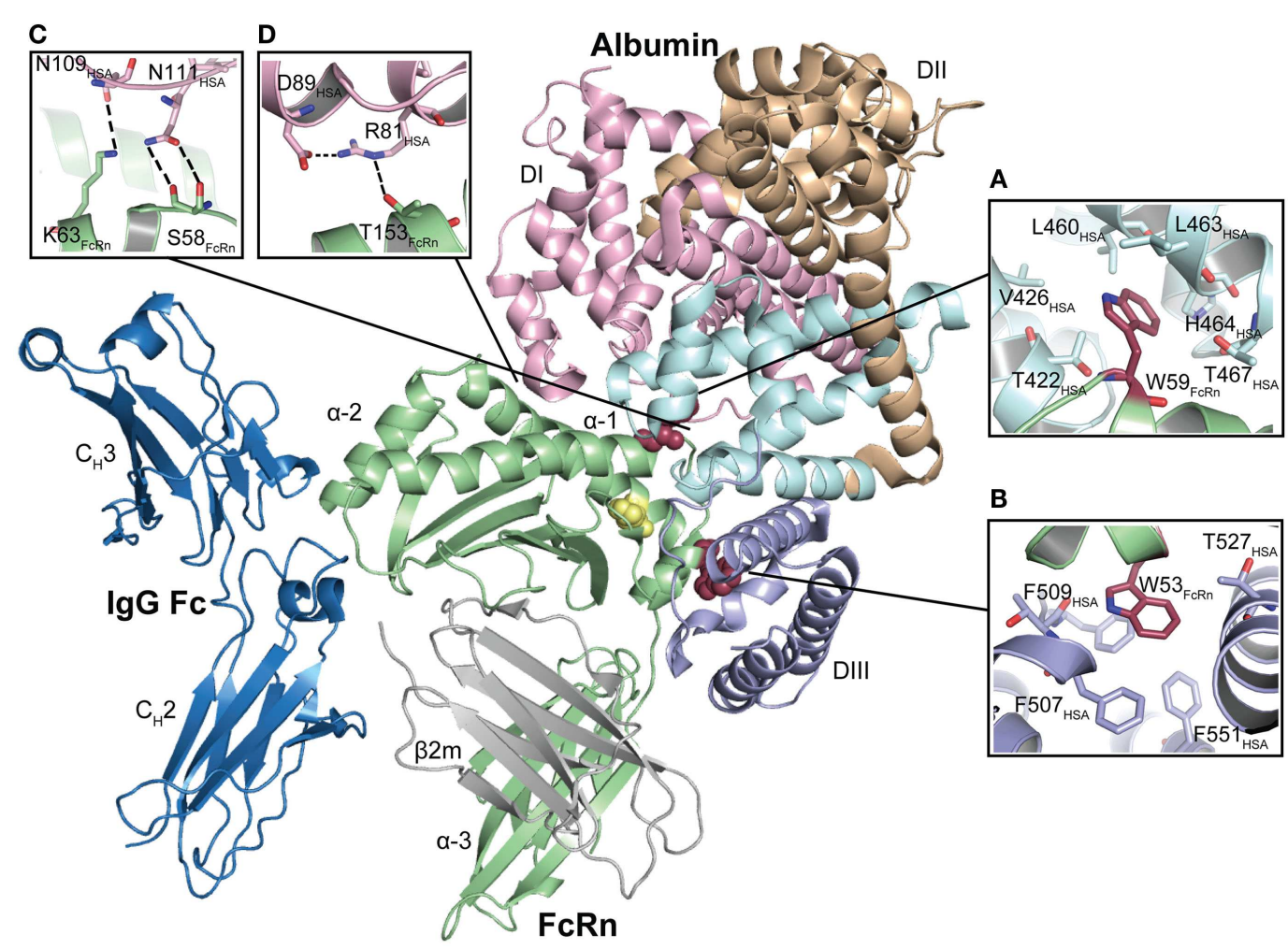

FIGURE 3 |The co-crystal structure of human FcRn bound to IgG-Fc and albumin. The illustration shows the ternary complex of human FcRn in complex with $\operatorname{lgG} \mathrm{Fc}$ and wild-type human albumin. The three domains of the $\mathrm{FcRn} H C(\alpha 1, \alpha 2$, and $\alpha 3)$ are shown in green and the $\beta 2 \mathrm{~m}$ subunit in gray. The IgG-Fc is shown in blue while the three domains of albumin are shown in pink (DI), orange (DII), and light blue (DIII). H166 that stabilizes the structure of the loop containing W51, W53, W59, and W61 is shown in yellow. The FcRn residues W53 and W59 are shown as red spheres. (A) FcRn-W59 makes contacts with a hydrophobic pocket in
DIIIA, which is composed of T467, T422, V426, L460, L463, and H464. (B) FcRn-W53 makes hydrophobic stacking with three phenylalanines in DIIIB (F507, F509, and F551). (C) A close-up of the structural areas of DI with N111 and N109 of albumin DI interacting with the FcRn residues S58 and K63, respectively. (D) A close-up of the structural interface showing the intramolecular hydrogen bond between albumin R81 and D89, and the interaction between FcRn-T153 and R81. The figures were made using PyMol and the crystal structure data of human FcRn in complex with IgG-Fc and albumin (4NOU) (69). selected by yeast display and has considerably improved affinity for FcRn at both $\mathrm{pH} 6$ and $\mathrm{pH}$ 7.4. The two co-crystal structures show highly similar modes of binding, but with some differences that are likely due to the introduced mutations in HSA13 DIII. However, the hydrophobic cores of the interaction interfaces are similar, and in both, the exposed FcRn-W53 and FcRn-W59 make contact with hydrophobic pockets in DIIIB and DIIIA, respectively (Figures 3A,B). More specifically, FcRn-W59 forms hydrophobic interactions with T422, V426, L460, L463, and T467 in albumin DIIIA (Figure 3A), while FcRn-W53 is inserted into a hydrophobic pocket between two $\alpha$-helices in DIIIB, which comprises three phenylalanine residues F507, F509, and F551 as well as T508 and T527 (69) (Figure 3B). The crucial residue K500 interacts with E46 within the $\alpha 1$-domain of FcRn, as well as forming an intra-molecular interaction with E531 of DIIIB (69). Further, the interaction of $\mathrm{FcRn}-\mathrm{W} 53$ with albumin requires a conformational change in albumin that comprises residues 500-510, which are part of a long loop that connects DIIIA and DIIIB. The two key residues $\mathrm{H} 510$ and $\mathrm{H} 535$ are located within this loop, and take part in the $\mathrm{pH}$ regulation of the $\mathrm{FcRn}$-albumin interaction by stabilizing the position of the loop at acidic $\mathrm{pH}$, which subsequently allows insertion of FcRn-W53 into DIIIB (69). In addition, H510 interacts with the fully conserved W176 and N173 in human FcRn (69). The third histidine, H464, is part of a hydrophobic environment that accommodates FcRn-W59 (69). Interestingly, the binding site for fatty acids within DIII overlap with the interaction sites for FcRn-W59 and FcRn-W53 (72) (discussed later).

Furthermore, both co-crystal structures show that two exposed loops within DI of albumin are in contact with residues of the $\alpha 1-\alpha 2$ helices of FcRn. In the wild-type complex, N109 and N111 form contacts with K63 and S58 of FcRn, respectively (Figure 3C). Albumin D89 and R81 form an intramolecular hydrogen bond, and R81 interacts with T153 of the receptor (Figure 3D). Notably, $\mathrm{N} 111$ has different conformations in the two co-crystals and may thus have alternative orientations. However, these studies did not experimentally address the impact of DI $(69,72)$. Although the docking model does not completely resemble the experimental crystal structures, it has guided the mapping of structural areas on both the receptor and albumin that are important for the interaction (70). Moreover, targeting of residues within the DI loops by site-directed mutagenesis has confirmed that the loops indeed contribute to FcRn binding (90). 
Interestingly, the crystal structures also suggest that albumin may make contact with the $\beta 2 \mathrm{~m}$ subunit, which involves longrange interactions between $\beta 2 \mathrm{~m}-\mathrm{R} 12$ and $\mathrm{E} 50$ with the side chain of albumin E505 and the backbone carbonyl of F502 (69). Again, differences are seen between the complexes containing wild-type albumin and HSA13. In one of the HSA 13 complexes, K573, which is located in the middle of the last $\alpha$-helix of albumin, interacts with $\beta 2 \mathrm{~m}-\mathrm{E} 69$ and S20 (72). Curiously, this interaction is not found in the other complexes.

Further, Oganesyan and colleagues have reported a co-crystal structure of human FcRn in complex with both wild-type albumin and an Fc fragment derived from an engineered IgG variant with improved binding to the receptor (69). As previous data have suggested, the mode of albumin binding is not altered in the presence of $\operatorname{IgG}(69)$.

\section{THE LIGAND BINDING PROPERTIES OF ALBUMIN}

The three domains of albumin contain binding pockets for a plethora of small endogenous and exogenous substances $(6,86)$. Thus, albumin acts as a molecule-taxi that transports essential substances and waste products in the bloodstream to their target sites. An illustration of a crystal structure of human albumin in complex with fatty acids is shown in Figure 2. Although the three domains are similar in structure, the interfaces are not, meaning that the orientation of DII relative to DI is different from the orientation of DIII relative to DII (84). In regard to binding of fatty acids, it has been shown that there are seven binding sites distributed asymmetrically throughout the tertiary structure of albumin (84, 87, 91) (Figure 2). Furthermore, crystallographic studies have shown that there are variations in the relative orientation of the domains, which likely arises from inherent flexibility of the loops and the domains. For instance, the structure of defatted human albumin has been determined in three distinct crystal forms, each of which shows different packing contacts, where the position of DIII varies $(83,84)$. The binding sites for different ligands and drugs are referred to either as fatty acid binding sites, drug binding sites 1 and 2, or Sudlow's sites 1 and 2, as highlighted in Figure 2.

Under normal conditions, albumin carries $0.1-2.0$ moles of fatty acids, but it can bind more in case of disease $(92,93)$. Structural analyses have shown that binding of fatty acids induces conformational changes that may affect binding of other ligands and drugs (94-99). As binding of FcRn engages two of the albumin domains, it raises an interesting question as to whether ligand binding to albumin will affect receptor binding and transport properties. Such knowledge is also of importance in design of novel albumin-based therapeutics, so as to control their pharmacokinetics. Interestingly, Schmidt and colleagues have shown that saturation of albumin with fatty acids interferes greatly with FcRn binding (72). This could be explained by steric hindrance, as DIII contains a high-affinity fatty acid binding site, right where the FcRn-W59 residue interacts $(69,72,100)$. Thus, it is of great importance to understand whether and how different endogenous ligands and drugs are affecting the interaction with FcRn, as it may well have significant impact on transport and deposition at different body sites. The knowledge will certainly be important for design of engineered albumin variants for various applications.
In addition, albumin has one free cysteine (C34) within a pocket of DIA that is partly exposed (Figure 2). This free sulfhydryl group is a site for binding of metals ( $\mathrm{Au}$ and $\mathrm{Pt}$ ) and nitric oxide (101, 102), but has also been conjugated to drugs (discussed later). The C34 residue is not in proximity to the FcRn binding site on DI, but it remains to be addressed whether conjugation to this site may impact receptor binding and transport.

\section{FcRn AS A HALF-LIFE REGULATOR}

The direct involvement of FcRn as a homeostatic regulator of IgG levels was first demonstrated in $\beta_{2}$ m-deficient mice $(9,10$, 58). These mice do not express a functional FcRn and consequently have reduced levels of circulating $\mathrm{IgG}$ as well as rapid clearance of injected $\operatorname{IgG}(9,10,58)$. Later, inspection of mice lacking the FcRn HC revealed a similar reduction in serum levels of IgG and albumin $(11,103)$. These mice have serum levels of IgG and albumin fourfold to fivefold and twofold to threefold lower than that of normal mice, respectively $(11,103)$. Further support for the great importance of FcRn for half-life regulation was provided by a study of a rare human syndrome, named familial hypercatabolic hypoproteinemia, diagnosed in two siblings from a consanguineous marriage, who showed very low serum levels of IgG and albumin that correlated with abnormally low expression of FcRn (104). The siblings carried a mutant $\beta_{2} \mathrm{~m}$ subunit with an alanine to proline substitution at amino acid 11 in the signal sequence, which resulted in $80-90 \%$ reduced expression of $\beta_{2} \mathrm{~m}$-associated proteins such as FcRn (12).

The plasma concentration of albumin in FcRn knock-out mice is roughly half of that in normal mice $(11,105)$. In humans, the average plasma concentration of albumin is $40 \mathrm{mg} / \mathrm{ml}(>600 \mu \mathrm{M})$, and as such a $70 \mathrm{~kg}$ person has a total albumin pool of $360 \mathrm{~g}$, where $120 \mathrm{~g}$ constitute the intravascular albumin, which is in constant exchange with the extravascular pool. Studies in mice have demonstrated that FcRn rescues an equivalent amount of albumin in a day as the liver produces, which is estimated for adult humans to be $13 \mathrm{~g}$ per day (105). Thus, from an evolutionary perspective, the use of a common receptor to rescue IgG and albumin from degradation is far more economical than using energy on additional synthesis.

The serum levels of IgG and albumin are regulated by several factors including their size above the renal clearance threshold (discussed below), the balance between the rate of synthesis by plasma cells and hepatocytes, and the level of FcRn expression. Thus, if the serum level of albumin drops, the half-life should increase due to increased rescue caused by less competition for FcRn binding. This is indeed the case, and demonstrated in human studies conducted in the 1950-1970, where the half-life of radiolabeled albumin injected into people with abnormally low albumin levels, was shown to be 50-100 days (106-108). In addition, using so-called Nagase analbuminemic rats, which are genetically deficient in albumin synthesis, the half-life of injected rat albumin was measured to be 2.2 times longer than in normal rats $(109,110)$.

Moreover, the albumin gene exhibits a significant degree of DNA mutations causing analbuminemia or alloalbuminemia. More than 70 genetic variants have been characterized, and represent site-specific, splice-site, or frame-shift variants $(111,112)$. Alloalbuminemia (bisalbuminemia) is an inherited or acquired 
condition characterized by the presence of altered albumin variants where heterozygotes have two forms of the protein. Furthermore, analbuminemia is a rare recessive disorder in which subjects have little or no $(<1 \mathrm{mg} / \mathrm{ml})$ circulating albumin caused by a variety of mutations in the albumin gene, and is exhibited only by homozygous subjects. Although albumin is the most common serum protein, these conditions are benign, and surprisingly few biochemical effects and clinical symptoms have been observed. However, association between hypoalbuminemia and mortality has been reported for patients with diseases such as acute heart failure, renal disease, cancer, stroke, pneumonia, dementia, and hemodialysis (113-117).

Several mutant albumin variants have been reported with reduced half-life compared to wild-type albumin. One example is the Casebrook variant, which has a single point mutation in the C-terminal DIII (D494N), which introduces an N-glycosylation site. In heterozygous carriers, only $35 \%$ of total serum albumin corresponds to Casebrook $(118,119)$. We have recently shown that this albumin variant has a twofold reduced affinity for FcRn, which suggests that it will have shorter half-life in the presence of normal albumin that will compete more efficiently for binding to the receptor (70). This is supported by a study performed in rabbits where the D494N mutation was introduced in rabbit albumin to the effect of reducing the half-life twofold compared with normal albumin (4.7 versus 2.8 days) (119). Another example is a truncated albumin variant, named Bartin, which lacks almost the entire DIII, except for the first 25 amino acids, due to a nonsense mutation (120). This variant, when recombinantly expressed, did not show detectable binding to FcRn, which is in line with the fact that DIII is the major binding domain for FcRn (89). In fact, albumin variants with either C-terminal elongation or truncation constitute only $2-30 \%$ of the total albumin in heterozygous carriers, which has been suggested to be caused by instability of the abnormal albumin $(89,121,122)$. However, it may well be due to altered or lack of FcRn binding.

\section{FcRn-MEDIATED RECYCLING AND TRANSCYTOSIS}

The neonatal Fc receptor transports its ligands via either of two distinct pathways, cellular recycling or transcytosis. Illustrations of the FcRn-mediated recycling and transcytotic pathways are shown in Figures $4 \mathbf{A}-\mathbf{C}$. The steps of the recycling process have been studied using advanced live cell fluorescence imaging in human endothelial cells over-expressing FcRn (123-128). These elegant studies have revealed that FcRn predominantly resides within acidified endosomes where it binds IgG that is taken up by fluid-phase pinocytosis. The low $\mathrm{pH}$ within the endosomes triggers binding, which results in recycling of the FcRn-IgG complex to the cell surface where exposure to an increasingly more neutral environment favors exocytosis of IgG out of the cell in a so-called kiss-and-run or prolonged-release manner (125). By contrast, proteins that do not bind FcRn will be sorted to late endosomes and subsequently to lysosomes where they are degraded $(124,126)$. The process is regulated by small Ras-like GTPases such as Rab4, Rab5, and Rab11 that are present on FcRn containing endosomes, as indicated in Figures 4A,B. Notably, Rab4 and Rab11 are known to be involved in recycling from sorting endosomes to the plasma membrane, whereas Rab5 is an early endosomal marker (129). Ward and colleagues have shown that during exocytosis, FcRn is sorted into tubulovesicular compartments that are positive for Rab4 and Rab11, and that only Rab11 is associated with the receptor upon exocytosis at the plasma membrane $(127,128)$. Importantly, the studies have revealed that there is overlap between the Rabs in the different compartments, so-called Rab conversion, as endosomes mature (130).

As FcRn binds both IgG and albumin at independent binding sites, albumin is likely to follow the same pathway as $\mathrm{IgG}$, although so far, no imaging studies have been done on trafficking of the ternary complex. The non-cooperative binding of the ligands is illustrated using a high affinity 26-amino acid peptide dimer SYN1436. The peptide binds to the IgG site of the receptor and blocks FcRn-mediated transport of IgG, resulting in an $80 \%$ reduction in serum levels of IgG in cynomolgus monkeys without reducing serum albumin levels $(131,132)$.

Furthermore, this raises the question of which cells and organs that contribute to FcRn-mediated salvage. So far, it has been shown that both non-hematopoietic and hematopoietic cells are of equal importance $(49,51)$. Studies in mice have identified endothelial cells and myeloid-derived professional antigen presenting cells as key players (49). When the expression of FcRn was conditionally deleted from these cell types, the serum levels of IgG and albumin were reduced by fourfold and twofold, respectively $(49,51)$. The contribution of the different cell types will depend on the rate of uptake, the level of FcRn expression, and the abundance of the ligands. In addition, the expression of the receptor can be up- or down-regulated by pro-inflammatory substances and cytokines, which add another level of regulation $(133,134)$.

As initially described, FcRn binds IgG derived from the mother's milk and mediates transcytosis across the neonatal rat intestine (135-137). While the expression of FcRn in the rodent intestine is developmentally down-regulated, it is constitutive in humans throughout life $(21,138,139)$. Several studies have shown that human FcRn can transport both monomeric IgG and IgGcontaining immune complexes across mucosal epithelial barriers in both directions, a process that also relies on a $\mathrm{pH}$ gradient (19, 20, 23, 140, 141).

Using polarized Madin-Darby canine kidney cells that overexpress human FcRn, it has been demonstrated that the receptor transports IgG from either apical or basolateral side into the recycling endosome $(75,78)$. As shown in Figure $4 B$, the actin motor myosin $\mathrm{Vb}$ and the GTPase Rab25 regulate a sorting step that determines transcytosis without affecting recycling (142). In addition, it was demonstrated that Rab11 is dispensable for transcytosis, but regulates recycling to the basolateral side (142).

These findings raise the question of whether or not FcRn is capable of mediating transcytosis of albumin across the same cellular barriers, and whether the stoichiometry of the interaction with FcRn plays a role, as albumin binds FcRn in a 1:1 manner, while IgG is homodimeric and has two binding sites for FcRn $(11,60)$. This is interesting, as albumin transport across epithelia would allow for delivery of albumin-based therapeutics. However, no in vitro cellular studies have so far demonstrated that FcRn can transport albumin efficiently alone or in the presence of IgG across polarized cells. One study using MDCK cells overexpressing rat FcRn could not detect transcytosis of rat albumin 


\section{A}

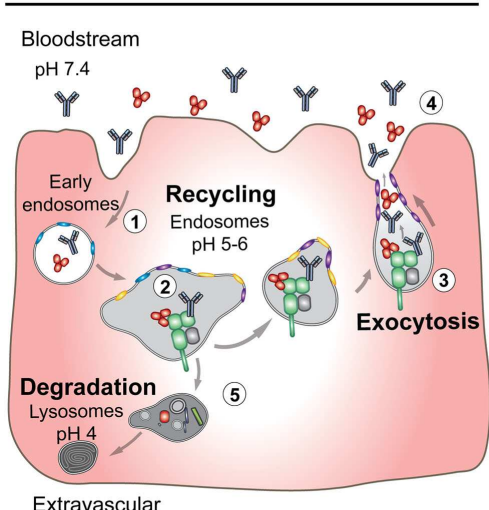

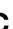

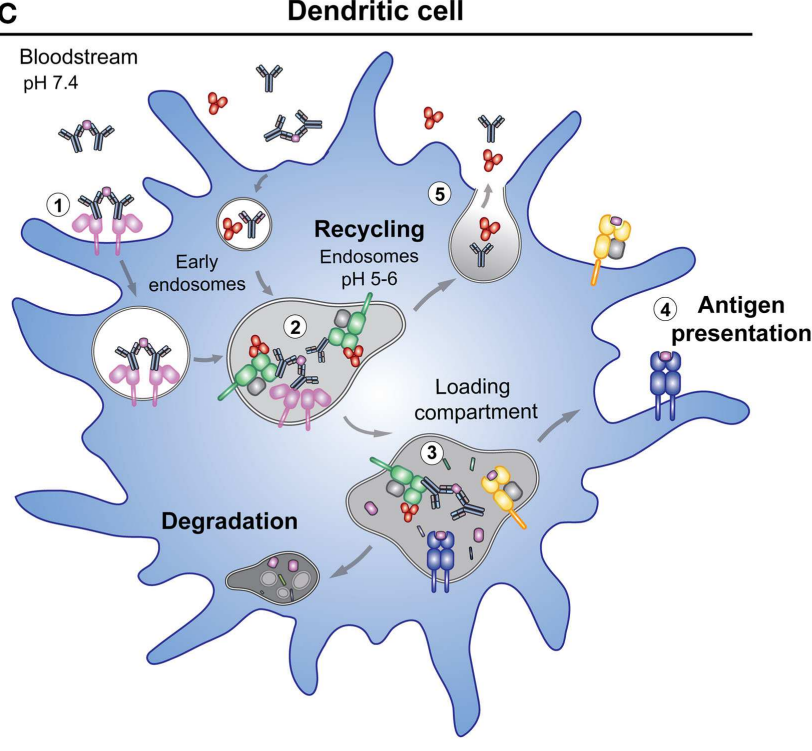

B

Epithelial cell
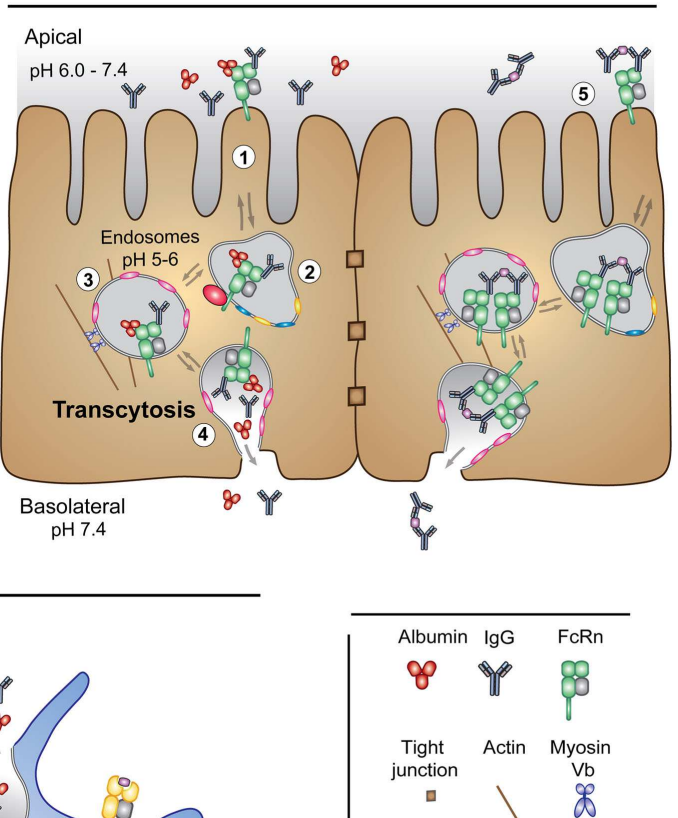

Calmodulin Antigen IgG-IC

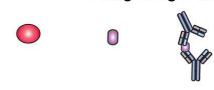

FcyR MHC I MHC

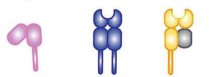

Rab5 Rab4 Rab11 Rab25

000

$\mathrm{pH}$ gradient

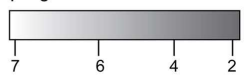

FIGURE 4 | FcRn-mediated transport pathways. (A) A schematic illustration of the model of FCRn-mediated recycling pathway of its two ligands in an endothelial cell lining the vascular space. (1) IgG and albumin are taken up from the blood by pinocytosis in Rab5 positive early endosomes. (2) FcRn, predominantly localized to acidified endosomes, binds the ligands in Rab4 and Rab11 positive recycling compartments. (3) The ternary complex is recycled to the cell surface as Rab11-positive tubules, which results in exocytosis of the ligands. (4) The neutral $\mathrm{pH}$ of the bloodstream leads to release of the ligands. (5) Proteins that do not bind to the receptor will be sorted to late endosomes and further to lysosomes for degradation. (B) An illustration of a polarized epithelial cell layer and the model of FcRn-mediated bidirectional transport. (1) The acidic $\mathrm{pH}$ present at certain mucosal sites (apical side) may result in binding of the ligands to FcRn at the cell surface in addition to within recycling endosomes. (2) The transcytotic pathway may be regulated by calmodulin that binds to the cytoplasmic tail of FcRn, and (3) depends on the actin motor myosin $\mathrm{Vb}$ and Rab25. (4) Endosomes fuse with the basolateral side of the cells, which lead to release of the ligands upon exposure to neutral pH. (5) FcRn may also transcytose IgG-containing immune complexes across the polarized cell layer. (C) The illustration shows a DC that expresses both FcRn and classical Fc $\gamma$ receptors. (1) Cross-binding of an IgG-containing immune complex to surface-expressed $\mathrm{Fc}_{\mathrm{C}} \mathrm{Rs}$ leads to internalization into early endosomes. (2) The immune complexes engage FcRn within acidified endosomes. (3) FcRn directs the lgG-containing immune complexes to loading compartments for processing followed by loading of antigenic peptides onto $\mathrm{MHC}$ I (in terms of cross-presentation) and $\mathrm{MHC}$ II. (4) $\mathrm{MHC} \mathrm{I} \mathrm{and} \mathrm{II} \mathrm{traffic} \mathrm{to} \mathrm{the} \mathrm{plasma} \mathrm{membrane} \mathrm{for} \mathrm{presentation} \mathrm{of}$ peptides to T-cells. (5) Monomeric ligands may also be recycled by DCs.
(78). Several studies have demonstrated that IgG-based fusions, vaccines, and nanoparticles can be delivered in an FcRn-dependent manner across mucosal barriers (25-32). Interestingly, in mice, albumin was found in saliva $(1-3.0 \mu \mathrm{g} / \mathrm{ml})$, feces $(0.1 \mathrm{mg} / \mathrm{ml})$, and the small intestine $(0.5 \mathrm{mg} / \mathrm{ml})(143)$, and in a human study, more albumin $(655.0 \mu \mathrm{g} / \mathrm{ml})$ than $\operatorname{IgG}(50.0 \mu \mathrm{g} / \mathrm{ml})$ was found in the fluid of the respiratory tract (144). Illustrations showing the models for FcRn-mediated recycling and transcytosis are given in Figures $4 \mathrm{~A}-\mathrm{C}$.

\section{THE ROLE OF FCRn IN THE KIDNEYS}

Serum persistence of soluble proteins also depends on the renal clearance threshold, which prevents clearance of proteins larger than $60-70 \mathrm{kDa}$ from the body through the urine. The nephron, 
its filtration barrier, and a model for protein reabsorption are illustrated in Figure 5. Specifically, the kidneys receive blood from the renal arteries, which reach the glomerular filtration barriers that form three size- and charge-selective filters. These block the passage of cells and larger proteins into the urine (145). First, the blood is filtered in the glomerular capsule of the nephrons, and then the filtrate is transported via the proximal convoluted tubule where water and essential proteins are reabsorbed. As the kidneys filter roughly $180 \mathrm{l}$ of blood each day, it means that astonishing $>7 \mathrm{~kg}$ of albumin and $>2 \mathrm{~kg}$ of IgG are processed by the kidneys.

The first study addressing a potential role of FcRn in the kidneys showed that the receptor is expressed in specialized epithelial cells named podocytes (46), which are part of the glomerular capsule, and the filtration barrier (Figure 5A). Akilesh and colleagues demonstrated that $\mathrm{IgG}$ accumulated at this barrier in mice lacking FcRn (50). Based on this finding, FcRn-positive podocytes were postulated to be the key cells responsible for removal of IgG from the glomeruli. Notably, delayed clearance of IgG may lead to serum-induced nephritis, which may indicate that the receptor could be involved in the pathology of diseases such as systemic lupus erythematosus, where kidney damage is commonly caused by deposition of IgG and immune complexes at the glomerular barrier. Thus, the presence of FcRn may provide a mechanism to clear IgG from the glomerular basement membrane and deliver it intact into the glomerular filtrate. Although the same study did not address how albumin is handled, it has been shown that podocytelike epithelial cells endocytose albumin that co-localizes with FcRn (146). The glomerular filtrate that enters the proximal convoluted tubule is well known to contain albumin, and it has been demonstrated that albumin is retrieved by proximal tubule cells (147).

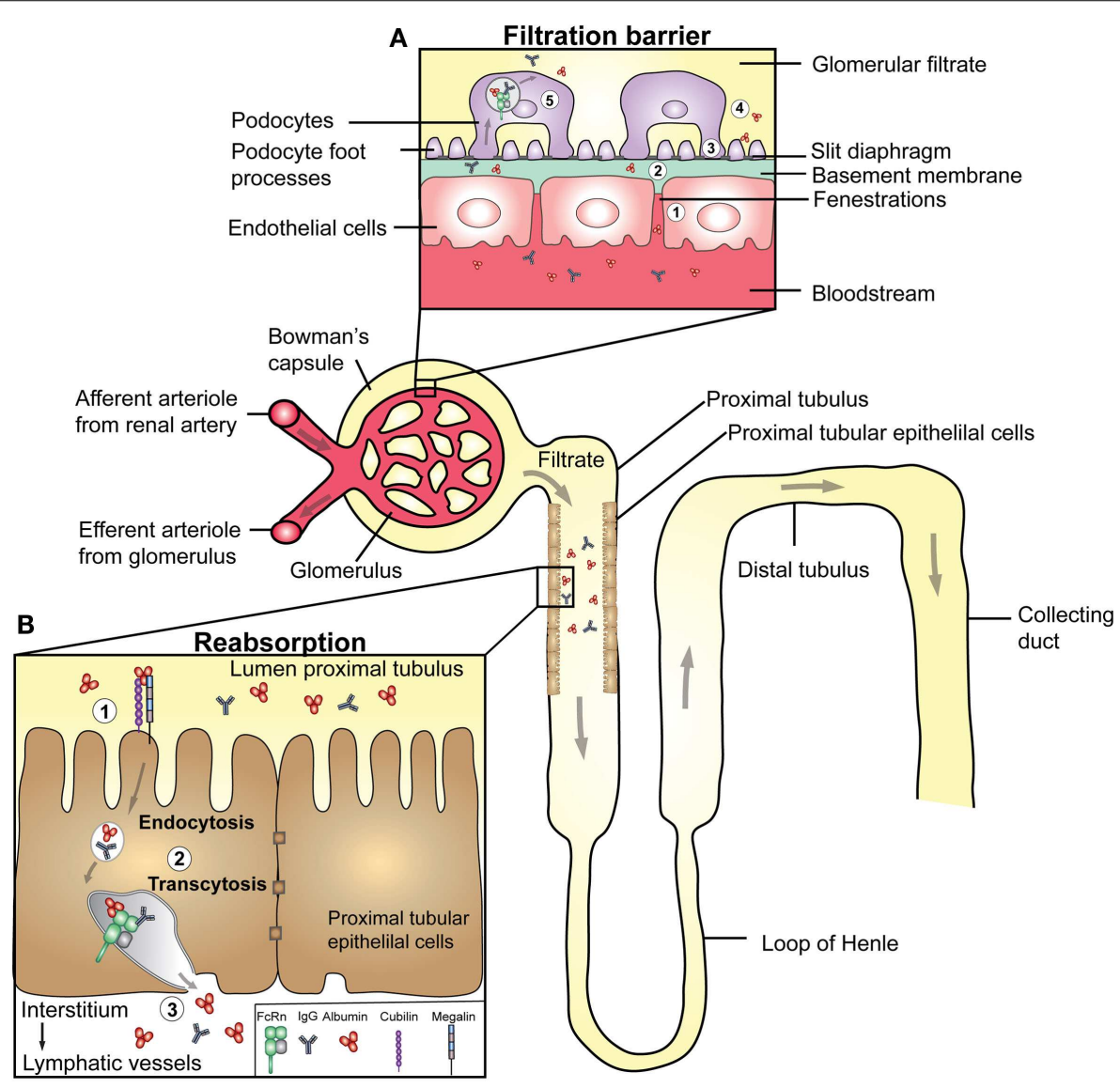

FIGURE 5 | Transport of IgG and albumin in the kidneys. A schematic cartoon showing the nephron of the kidney and transport pathways. Blood enters the kidneys through the afferent arteriole from the renal artery, proceeds through the capillaries of the glomerulus where filtration occurs, and exits through the efferent arteriole. (A) The filtration barrier of the glomerulus. (1) The first barrier is the fenestrations between endothelial cells of the glomerular capillaries. (2) The second barrier is the basement membrane, a non-cellular layer consisting of extracellular matrix molecules, which make up charged pores. The podocytes are specialized epithelial cells that encapsulate the capillaries and the basement membrane, and form the outermost layer of epithelial cells facing the glomerular filtrate. (3) The foot processes of the podocytes have slits between them (slit diaphragms) that form the third layer of the filtration barrier. (4) As the pore size of the barrier is between $60-70 \mathrm{kDa}$, close to the size of albumin $(66.5 \mathrm{kDa})$, some albumin passes the filter. (5) Podocytes express FcRn, and may transcytose IgG and albumin to the glomerular filtrate to prevent clogging of the filter. (B) The glomerular filtrate enters the proximal tubuli where proximal tubular epithelial cells lining the lumen of the tubuli are involved in reabsorption of albumin and IgG, and thus prevent loss into the urine. (1) Proximal tubular epithelial cells also express the cubilin/megalin receptor complex that binds albumin. (2) In acidified endosomes, FcRn binds the ligands, and facilitate transcytosis. (3) The ligands are delivered to the interstitial space of the kidneys followed by drainage to lymphatic vessels and re-entry to the blood circulation. 
These cells also express FcRn (46), and several lines of evidence support an important role of FcRn in retrieval of albumin (148150). The transport pathways of IgG and albumin in the nephron are shown in Figure 5.

It has been demonstrated that FcRn-deficient mice secrete more albumin into the urine than normal mice, and the same was observed for normal mice transplanted with a kidney lacking FcRn (150). When FcRn-deficient mice received an FcRn-expressing kidney by transplantation, increased serum levels of albumin were observed. In contrast, FcRn-deficient mice showed minimal urinary excretion of IgG, which increased to normal levels when knock-out mice were transplanted with a single FcRn expressing kidney (150). This may imply that the glomeruli get clogged with IgG in the absence of FcRn, while it is otherwise transported by the podocytes.

Furthermore, recent studies using a transgenic mouse strain with podocyte-specific expression of doxycycline-inducible tagged mouse albumin showed that albumin secreted into the filtrate is subsequently reabsorbed by proximal tubular cells, which resulted in increased serum levels (149). In addition, deletion of FcRn expression abolished uptake of albumin, and also IgG in proximal tubular cells $(148,149)$. Collectively, these data support a key role for FcRn in the kidney tubular system, where FcRn protects albumin and IgG from being excreted into the urine, a mechanism that likely relies on directed $\mathrm{pH}$-dependent transcytosis of intact ligands back to the circulatory system. Thus, the data point to the first evidence of FcRn-mediated transcytosis of albumin as part of a ternary complex with IgG.

However, the mechanisms responsible for handling albumin in the kidneys may not necessarily rely on FcRn only, as several studies claim that uptake of albumin by the proximal tubular cells is an active process that depends on a receptor complex consisting of cubilin and megalin (151-154) (Figure 5B). Homozygous deletion of cubilin in mice is lethal, and studies done in heterozygous individuals showed reduced renal proximal tubular uptake, increased urinary loss, and decreased blood levels of albumin (152, 153). Further, dogs with a defective cubilin gene excrete large amounts of albumin due to an almost complete lack of reabsorption (153). In addition, cubilin has been shown to associate with megalin, and in line with this, both mice and humans deficient in megalin expression have reduced tubular reabsorption of albumin (153, 155, 156). As illustrated in Figure 5B, these findings thus raise the possibility that FcRn may work in concert with the megalin and cubilin complex. Such a pathway may then serve as a selective process where only albumin with intact receptor binding properties are returned to the blood, while albumin with bound ligands is excreted in the urine or sorted to intracellular compartments destined for degradation.

\section{A REGULATORY ROLE OF FcRn IN THE LIVER?}

The liver receives six times more blood per day than the kidneys due to supply of both arterial blood from the heart, and venous blood from the digestive tract. The main cell type (70-80\%) of the liver is specialized epithelial cells named hepatocytes, which have an apical side facing the bile canaculi, and a basolateral side that is in contact with the blood (157). This means that large amounts of IgG and albumin are in direct contact with endocytically active hepatocytes. As such, it is of great interest to address the importance of IgG and albumin receptors including FcRn in liver cells in the context of IgG and albumin homeostasis.

Despite the fact that the amount of IgG in blood is five times higher than that of IgA, astonishingly little IgG enters the bile compared with secretory IgA (158). Likewise, even though albumin is produced by hepatocytes that face both blood and bile ducts, the level of albumin in blood is 100-fold higher than that found in the bile $(158,159)$. However, there is a scarcity of data on which transport mechanisms operate in hepatocytes to maintain serum to bile ratio of IgG and albumin, rescuing these ligands from catabolism and directing newly synthesized albumin to the blood. Only a few papers have addressed the expression and function of FcRn in the liver $(53,160,161)$. One shows expression of FcRn in the rat liver and that it binds IgG in a $\mathrm{pH}$-dependent manner (53). Thus, there is a great need for studies addressing the impact of FcRn in the liver, so as to understand the biology and biodistribution of IgG and albumin. In this context, it is highly interesting that the liver is the principal site for albumin synthesis. Studies addressing these aspects will shed new light on how to avoid liver toxicity.

\section{THE ROLE OF FcRn IN IMMUNE CELLS}

The neonatal Fc receptor is expressed in mouse and human myeloid-derived antigen presenting cells such as monocytes, macrophages, and dendritic cells (DCs) $(42,49,51)$. Besides being of importance in half-life regulation, FcRn in these cells has a role in antigen presentation following uptake of IgG-containing immune complexes $(162,163)$. The different sorting pathways for IgG and IgG-containing immune complexes are illustrated in Figure 4C. Whereas monomeric IgG is efficiently recycled by FcRn in DCs, IgG-immune complexes are taken up following binding to classical Fc $\gamma$ receptors expressed on the cell surface, before FcRn is recruited within acidified endosomes, followed by transport to a degradative pathway leading to antigen loading on either MHC class I or II for presentation to T cells $(162,163)$ (Figure 4C). In particular, FcRn has been shown to be of great importance in crosspresentation mediated by monocyte-derived CD $8-C D 11 b+D C s$, a pathway that was recently shown to be critical in cancer protection in mice (164). The role of FcRn in antigen presentation has been thoroughly reviewed elsewhere $(163,165)$.

Notably, the invariant chain (Ii) is an important regulator of MHC class I and II transport $(166,167)$, and one study showed FcRn association with Ii in DCs as well as in cytokine-stimulated epithelial and endothelial cells (168). The association of the FcRnIi complex was initiated within the ER, and Ii association targeted the receptor to late endosomes or lysosomes. Thus, Ii may be a modulator of FcRn trafficking of immune-complexes (168).

As efficient uptake and delivery of immune complexes to FcRn is dependent on initial binding to the Fc $\gamma$ receptor, it is of interest to address whether albumin fusions or complexes are excluded from this pathway or not. Interestingly, albumin has been shown to be efficiently taken up by phagocytes of sentinel lymph nodes in mice, and when conjugated as a vaccine it resulted in increased accumulation in the lymph node followed by enhanced T-cell priming and anti-tumor efficacy (169). 


\section{THE ROLE OF FCRn AT IMMUNE-PRIVILEGED SITES}

Immune-privileged sites are characterized by limited or absence of immune surveillance and include the central nervous system, the eyes, testis, and placenta. With regard to FcRn, confocal microscopy studies have identified its expression in choroid plexus epithelium, which forms part of the blood-brain-barrier (BBB) (170), a finding, which suggested that the receptor may mediate efflux of IgG from the brain to the blood in a process of reverse transcytosis $(171,172)$. Indeed, in a murine model of Alzheimer's disease, it was shown that FcRn expressed within the BBB is involved in the removal of amyloid $\beta$-peptide specific IgG-immune complexes from the brain of older mice (173). However, another study is in conflict with this, and claims that FcRn is not responsible for the low levels of IgG in the brain relative to that found in plasma $(174,175)$. A more recent study, where $\operatorname{IgG}$ variants were injected intracranically in rats, showed that an IgG with improved FcRn affinity was removed faster from the brain compared to a mutant with no affinity for the receptor, which was present for a longer time post injection (172). Therefore, further studies are required to elucidate the function of $\mathrm{FcRn}$ at the BBB.

The neonatal $\mathrm{Fc}$ receptor is also found to be expressed in the eyes in a variety of tissues such as the cornea, lens epithelium, and retinal blood vessel, but not in the retinal pigment epithelium and the choroid $(44,52)$. Investigation in normal mice and mice deficient for FcRn has demonstrated that the receptor plays a role in removing intravitreally administered IgG via the blood retinal barrier for delivery into the blood in analogy to the process of reverse transcytosis described for the BBB (176). Another recent study shows that retinal endothelial cells express FcRn, which may imply that it is preventing IgG from transport across the blood-retinal barrier (44).

As albumin is present in blood in higher levels than IgG, the immune-privileged sites are exposed to both ligands; however, none of the above studies addressed the importance of FcRn on albumin transport at these barriers. In addition, the importance of FcRn in the testis has yet not been addressed.

\section{FcRn: A REGULATOR OF TRANSPLACENTAL TRANSPORT}

The transfer of passive immunity from mother to offspring was first attributed to the transfer of IgG across the intestine in neonatal rats via FcRn-mediated transcytosis, as discussed above. In humans, IgG is delivered via the placenta, and a human ortholog of FcRn was first cloned from specialized placental cells named syncytiotrophoblasts, and later these cells were shown to bind IgG (22, $24,177)$. However, to enter the fetal blood, IgG needs to cross not only the syncytiotrophoblasts but also the fetal endothelium. In addition to FcRn, another IgG binding receptor, Fc $\gamma$ receptor IIB, has been identified in placental endothelial cells and postulated to be involved in the shuttle of $\operatorname{IgG}$ to the fetus, but conflicting data exist (178-181). Using ex vivo placenta perfusions, it was demonstrated that an $\operatorname{IgG}$ molecule with no affinity for classical Fc $\gamma$ receptors is transported across the placenta, while an IgG with no affinity for FcRn is not (24). In addition, an engineered IgG variant with improved affinity for FcRn was transported more efficiently than wild-type IgG (182). These data strongly suggest that transport of $\operatorname{IgG}$ is solely dependent on FcRn.
With regard to transfer of albumin, the literature is conflicting. Early studies from the 1950-1960s conclude that transport of albumin to the fetus does not occur in mice, rats, and dogs (183-185), while reports from studies in rabbits and rhesus monkeys show that albumin is transported, although to a much lesser extent than $\operatorname{IgG}(183,186-188)$. More specifically, the levels of albumin in the fetus of rabbits were found to be $40 \%$ of that of the levels of maternally derived IgG (187), while in rhesus monkeys 15 - to 20 -fold lower levels of albumin were detected compared with IgG (186). In a human study from 1964, where radioiodinated IgG and albumin were injected into pregnant women in the last month of gestation, the levels of albumin in the offspring were measured to be only $14-15 \%$ of that found in the maternal blood, whereas the amounts of IgG were slightly higher than that found in the mothers (189). These studies indicate that there are differences across species, and that albumin is inefficiently transported across the placenta compared with IgG in rhesus monkeys and humans. Whether or not other albumin binding receptors are involved in albumin transport in the different cellular layers of the placenta is not known, but two studies have identified the cubilin/megalin complex in human syncytiotrophoblasts $(190,191)$. Hence, there is a great need for in-depth studies addressing how albumin and albuminbound cargo are handled by the cells of the placenta. For instance, the use of in vitro perfusion systems of human placenta combined with current molecular methods may facilitate new insights into the mechanisms at play.

\section{THE IMPACT OF CROSS-SPECIES BINDING DIFFERENCES}

As rodents are routinely used for pre-clinical screening of IgG and albumin-based therapeutics prior to studies in primates, it is necessary to understand how human IgG and human albumin bind mouse and rat $\mathrm{FcRn}$. Indeed, large differences in cross-species binding exist that need to be considered prior to in vivo evaluation of their pharmacokinetic and pharmacodynamic profiles $(17,18$, 192). The importance of such cross-species differences was first appreciated when it was found that human FcRn does not bind to mouse IgG, while mouse FcRn binds human IgG more strongly than mouse IgG, a finding that explains why human IgG has a longer serum half-life in wild-type mice than mouse IgG (192194). On the other hand, the lack of binding of mouse IgG to human FcRn gives an explanation for the disappointingly short in vivo persistence of therapeutic mouse IgG in humans (195, 196). For in vivo evaluation of human IgG therapeutics, the stateof-the-art mouse strains used are genetically modified as they lack expression of mouse FcRn and instead are transgenic for human FcRn $(193,197,198)$. Injected human IgGs have a long half-life in such mice, but their serum levels of endogenous IgG are low due to lack of binding to mouse IgGs. A more complete and attractive model would be mice that are transgenic for human IgG while also express human FcRn.

Regarding albumin, recent studies have demonstrated that FcRn from both mice and humans bind more strongly to mouse albumin than to the human form, and that mouse FcRn binds very poorly to human albumin $(17,18,199)$. These findings are in agreement with the fact that mice transgenic for human FcRn show higher levels of mouse albumin in blood than normal mice (11), and that the serum half-life of human albumin is similar to that 
of a human albumin variant (K500A) with considerably reduced affinity toward human FcRn (18). Another example is that the half-life of human albumin is only $15 \mathrm{~h}$ in normal rats compared to $49 \mathrm{~h}$ for rat albumin (200). Consequently, rodents have limitations as pre-clinical models for evaluation of human albumin variants and albumin-based therapeutics, as injected variants will be ignored by mouse FcRn in the presence of $40 \mathrm{mg} / \mathrm{ml}$ of endogenous mouse albumin. Similarly, human FcRn transgenic mice will rescue mouse albumin from degradation more efficiently than injected human albumin. These are critical matters to consider prior to evaluation of human albumin-based therapeutics. Thus, there is a great need for construction of novel mouse strains that are human FcRn transgenic and lack expression of mouse albumin, or where the gene for mouse albumin is replaced with the human counterpart.

\section{FcRn AND THERAPEUTIC APPLICATIONS}

The versatile roles of FcRn are increasingly appreciated by both academic labs and biotech companies, as new opportunities for therapy become available. Many examples of utilization of the biology of FcRn have given rise to new classes of IgG-based therapeutics. In light of the expanding interest and mapping of the relationship between FcRn and albumin, it is likely that such knowledge will pave the way for tailoring of albumin-based therapeutics.

As IgG is the fastest growing class of biotherapeutics, there is a great interest for optimization of effector functions and in vivo efficacy by manipulating the interaction with FcRn. As the interaction is $\mathrm{pH}$ dependent, the major challenge has been to improve binding without disrupting $\mathrm{pH}$-dependent binding. Despite this, several examples exist on successful engineering by targeting amino acid residues at the core or near the FcRn interaction site on IgG (201-206).

The same principle has just been revealed for human albumin, by showing that swapping of part of DIII or introduction of substitutions within DIII result in albumin variants with altered FcRn-binding properties (18, 70, 72, 89, 199). The first example of engineering was demonstrated by swapping DIII from mouse albumin onto DI-DII of human albumin, which resulted in a hybrid albumin with considerably improved binding toward mouse and human FcRn, whereas swapping of DIII of human albumin onto DI-DII of mouse albumin reduced binding considerably (199). Moreover, swapping of a stretch of amino acids corresponding to the last C-terminal $\alpha$-helix of mouse albumin onto the human counterpart gave rise to fourfold improved binding (199).

In another approach, yeast display was used to develop human albumin variants with a range of affinities toward human FcRn. One such variant (E505G/V547A) gained more than 10-fold improved affinity at $\mathrm{pH} 6.0$ with a minor increase at neutral $\mathrm{pH}$, which extended the half-life in human FcRn transgenic mice and cynomolgus monkeys by 1.5-fold and 1.3-fold, respectively (72). Notably, selected variants with three and four DIII substitutions were immunogenic when injected into human FcRn transgenic mice (72).

Furthermore, using an approach based on structural analysis and cross-species binding analyses, a single substituted human albumin variant (K573P) was identified with 12-fold improved affinity toward human FcRn at acidic $\mathrm{pH}$ without detectable binding at neutral $\mathrm{pH}$ (18). When evaluated in mice transgenic for human FcRn and cynomolgus monkeys, the engineered variant showed 1.4 and 1.6-fold extended half-life, respectively. Interestingly, replacement of K573 with any amino acid resulted in enhanced binding to human $\mathrm{FcRn}$ at acidic $\mathrm{pH}$, a finding that is not easily explained based on the available co-crystal structures $(18,69$, 72). Also, from an evolutionary perspective, it is interesting that all species have a proline at position 573, except for humans and orangutans. Notably, introduction of K573P in human albumin improved binding to mouse FcRn by more than 20-fold, demonstrating the importance of a proline at this position for optimal binding to mouse FcRn, and it explains partly why human albumin binds the mouse receptor poorly $(17,18)$. Interestingly, mutating amino acid residues in a loop of DI to alanines resulted in HSA variants with slightly improved binding to the receptor, and combining mutations in DI and DIII may thus give rise to variants with further improved FcRn binding properties (90).

\section{ALBUMIN TARGETING AND THERAPEUTICS}

The therapeutic efficacy of small proteins, peptides, and chemical drugs is hampered by short in vivo serum half-life as they are cleared rapidly by the kidneys or the liver. Two strategies for rescue are fusion to $\mathrm{Fc}$ or albumin. Such approaches have been extensively explored, and Fc-fused drugs are approved for clinical use. An example is Fc-fusion to the tumor necrosis factor (TNF) receptor (Etanercept, Enbrel ${ }^{\circledR}$ ), which blocks binding of TNF- $\alpha$ to cellular TNF receptor and thus inhibits pro-inflammatory activity in rheumatoid arthritis patients (207). Fc-fused therapeutics and vaccines have also been shown to cross mucosal barriers in an FcRn-dependent manner (25-32). Although such fusions bind FcRn, the biophysical nature of the fused drug may alter binding to FcRn (208).

In regard to albumin, its properties have been utilized in five distinguished drug delivery technologies; (1) genetic fusion to the $\mathrm{N}$ - or C-terminal end, (2) chemical coupling of low-molecular weight drugs, (3) association of drugs with hydrophobic pockets of albumin, (4) association of albumin-binding domains (ABDs) that are genetically fused to drugs, and (5) encapsulation of drugs into albumin nanoparticles $(15,16)$.

A number of reports exist on genetic fusion of therapeutic proteins to wild-type albumin. Examples are hirudin (209), CD4 (210), insulin (211), growth hormone (212), granulocyte colony stimulating factor (213), $\alpha$ and $\beta$ interferons (214-216), and antibody fragments (217-221). All have shown improved pharmacokinetics compared to non-fused counterparts. For instance, recombinant interferon $\alpha 2 \mathrm{a}$ has only a half-life of $4 \mathrm{~h}$ in humans, which is increased to $141 \mathrm{~h}$ when fused to albumin (214). Another example is recombinant coagulation factors that have very short half-life in humans. For instance, commercially available recombinant FVIIa (NovoSeven ${ }^{\circledR}$ ) has a half-life of only $2.4 \mathrm{~h}$ (222). As a result, patients require multiple and frequent infusions to manage bleeding episodes. But when the factors are fused to the $\mathrm{N}$-terminal end of albumin via flexible glycine serine linkers, they maintain activity and gain considerably extended half-life in both pre-clinical animals and humans (222-224). Such fusions have now entered clinical trials for treatment of hemophilia (225). In 
addition, the first albumin fusion that has entered the market is a fusion of glucagon-like peptide-1 (GLP-1) to wild-type albumin (Eperzan ${ }^{\circledR} /$ Tanzeum $\left.^{\circledR}\right)$, which was approved for treatment of type II diabetes in 2014 (226, 227). These examples pinpoint that the albumin fusion platform is a successful strategy for improving the in vivo efficacy of small therapeutic proteins. In addition, a favorable feature of genetic fusion is that it allows a simple one-step synthesis process with no need for in vitro chemical cross linking steps.

Such fusions were designed and constructed long before the relationship between albumin and FcRn was appreciated. This raises the question of whether genetic fusion of proteins to the $\mathrm{N}$ or C-terminal end of albumin, or both, compromises $\mathrm{pH}$-dependent binding to FcRn. One study has so far addressed this concern, where direct fusion of a peptide or an antibody single-chain variable fragment $(\mathrm{scFv})$ via a linker to the $\mathrm{N}$-terminal end gave no or only a minor reduction in binding affinity at acidic $\mathrm{pH}$, whereas fusion to the C-terminal had a more pronounced effect and at most twofold weaker affinity (199). Although the decrease in binding was minor, it may play a role in vivo when fusions are injected into animals or humans where it will compete for binding to FcRn in the presence of $40 \mathrm{mg} / \mathrm{ml}$ of endogenous albumin. Thus, binding to FcRn should be addressed for each fusion as the nature of various fusion partners may affect receptor binding differently.

The presence of high amounts of albumin at the site of tumors and inflamed tissues has been utilized for tumor targeting by chemical conjugation of drugs to albumin (228). One example is methotrexate for treatment of renal carcinomas and autoimmune diseases such as rheumatoid arthritis (229-231). It is likely that random conjugation of payloads to surface exposed amino acid residues on albumin will negatively affect clearance and FcRn transport. Another approach is nab-paclitaxel (Abraxane $\left.{ }^{\circledR}\right)$, which is composed of the lipophilic drug paclitaxel that is encapsulated with albumin under high pressure. The drug was approved in 2005 for treatment of metastatic breast cancer, and is currently in trials for treatment of non-small lung cancer, pancreas cancer, and melanoma (16, 232-236). Following administration, the nanoparticles dissociate and paclitaxel becomes associated with albumin in blood. Whether nanoparticles containing albumin are capable of interacting with FcRn remains to be addressed.

A more specific way to chemically target albumin is to utilize the free C34 on the DI of albumin. For instance, in the technology known as Drug Affinity Complex (DAC $\left.{ }^{\circledR}\right)$, drugs are specifically and stably conjugated to either exogenous or endogenous albumin (237). One such DAC-based drug is exendin-4, which is a GLP-1 homolog (CJC-1131) for treatment of type 2 diabetes that has entered clinical trials (238-240). The power of this technology is mirrored by the pharmacokinetics in humans, where the half-lives of GLP-1 analogs have been shown to be a few hours compared with 9-15 days for the C34-bound drug (241). Another example is an acidic sensitive prodrug of doxorubicin (Aldoxorubicin) that is rapidly bound to C34 after intravenous administration (237). The drug is conjugated via a linker that is cleaved upon exposure to an acidic environment as found in tumor tissues, and Aldoxorubicin is currently in clinical trials for treatment of sarcoma and glioblastoma (16). Whether the acidic-sensitive linker is protected or cleaved during FcRn-mediating transport remains to be investigated.
A more recent example is a designed ankyrin repeat protein (DARPin) with specificity for the epithelial cell adhesion molecule that has been modified in the N-terminal end by introduction of the non-natural amino acid azidohomoalanine. The modification enables linkage of site-specifically dibenzocyclooctyne to C34 of wild-type mouse albumin (242). The conjugate was shown to bind mouse FcRn, a strategy that extended the serum half-life of the DARPin from $11 \mathrm{~min}$ to $17.4 \mathrm{~h}$ in mice (242). As discussed above, targeting of C34 will presumably not interfere with FcRn binding and transport.

Albumin may also be utilized by reversible non-covalent association. Such a strategy excludes the need for in vitro conjugation as endogenous albumin is targeted post injection (243-245). One strategy is to utilize fatty acids as tags that can be conjugated to drugs, and association with albumin post injection, which results in extended half-life. An example is conjugation of a myristate tag to a lysine residue on the insulin analog detemir $\left(\right.$ Levemir $\left.^{\circledR}\right)$, which is approved for treatment of diabetes types 1 and $2(243,246$, 247). At the time of subcutaneous administration, the drug exists as hexamers that dissociate into monomers in blood and associate with circulating albumin. The procedure prolongs the half-life from 5-6 min for the peptide to 5-7 h for the albumin-targeted drug (15). Similar strategies using fatty acids as tags with improvement in pharmacokinetics have been described for insulin-based drugs (Tresiba ${ }^{\circledR}$ and Victoza $\left.{ }^{\circledR}\right)(248,249)$.

Furthermore, an albumin-binding minimal organic molecule [2-(3-maleimidopropanamido)-6-(4-(4-iodophenyl)butanamido) hexanoate] that has been chemically conjugated to a free cysteine residue engineered into the C-terminal end of an $\mathrm{scFv}$ fragment with tumor specificity, was shown to increase the half-life from 0.5 to $16.6 \mathrm{~h}$ in mice (250). In addition, the modified $\mathrm{scFv}$ showed superior tumor accumulation in tumor-bearing mice (250).

An alternative is to target albumin with anti-albumin binding antibody fragments (221). An illustrating example is a bi-specific $\mathrm{F}(\mathrm{ab}) 2$ fragment with one-arm that targets TNF and one that targets albumin, which showed a half-life fivefold longer than that of mono-specific anti-TNF F(ab)2. This half-life is comparable to that of rat albumin itself ( 42.5 versus $49.1 \mathrm{~h}$, respectively), which supports that the anti-albumin Fab does not interfere with FcRn binding and transport (221).

The same has been demonstrated using small albumin-binding domain $(\mathrm{ABD})$ antibodies $\left(11-13 \mathrm{kDa}\right.$; AlbudAb $\left.{ }^{\circledR}\right)$ selected to bind rat albumin with high affinity $(13 \mathrm{nM})$. The half-life in rats is $53 \mathrm{~h}$, which is equal to the half-life measured for albumin $(53 \mathrm{~h})$ (200). Notably, it has been demonstrated that this AlbudAb binds to the DII of albumin, which is not engaged in FcRn binding (200, 251). So-called nanobodies with specificity for albumin have also been selected (252).

Moreover, small peptides with specificity for albumin from several species have been selected using phage display technology, where the core sequence (DICLPRWGCLW) is functionally dependent on a disulfide bridge between the two cysteine residues (253). One of the selected peptides (SA21) had a half-life of $2.3 \mathrm{~h}$ in rabbits, significantly longer than the $7.3 \mathrm{~min}$ of an unrelated peptide of similar size (253). Moreover, when albumin binding peptides with a wide range of affinities were fused to a Fab, with specificity for human epidermal growth factor receptor 2 (HER2) 
(AB.Fab4D5) derived from the clinically approved trastuzumab (Herceptin $\left.{ }^{\circledR}\right)$, a correlation between albumin affinity and serum half-life was demonstrated, as fusions with peptides of low affinity were eliminated faster than fusions with strongly binding peptides (254). These data show that the pharmacokinetics of a protein of interest may be tailored as a function of albumin affinity.

Furthermore, AB.Fab4D5 has been tested for its ability to target HER2-positive tumors in allograft mouse models, and demonstrated rapid tumor targeting in addition to elimination from the blood faster than the parental antibody (255). Thus, a significantly improved tumor to normal tissue ratio was achieved. Notably, Fab4D5 accumulated in the kidneys, while AB.Fab4D5 did not, suggesting that the albumin binding peptide has a great impact on biodistribution and organ deposition (255). These effects may be explained by the increase in size above the threshold for renal clearance and maintained albumin binding to FcRn.

Another approach has been to utilize the ABD derived from Streptococcus protein G. For instance, anti-HER2 Fab4D5 has been genetically fused via its light chain C-terminal end to such an ABD, which prolonged the half-life to $21 \mathrm{~h}$ compared to only $2 \mathrm{~h}$ for the naked Fab4D5 in mice, and comparable to that obtained with Fab4D5 fused to albumin targeting peptides $(255,256)$. Also, less ABD-fused Fab4D5 accumulated in the kidneys relative to naked Fab4D5.

A similar approach has been used to improve the pharmacokinetics of a divalent anti-HER2 Affibody ( $\left.Z_{\text {HER2:342 }}\right)$ molecule genetically fused to ABD. An Affibody is a small scaffold $(\sim 7 \mathrm{kDa})$ derived from the IgG binding domain of staphylococcal protein A that is used for construction of combinatorial libraries and target selections (257). Interestingly, high tumor uptake of radiolabeled anti-HER2 Affibody ( $Z_{\text {HER2:342 }}$ ) fused to ABD was demonstrated in HER2-positive microxenograft mice, where 25-fold reduction in kidney accumulation compared with the Affibody lacking ABD was observed (258). Thus again, non-covalent association with albumin was used to redistribute the therapeutic agent to avoid kidney accumulation. In regard to FcRn, it has been demonstrated that ABD, both alone and when fused to anti-HER2 Affibody $\left(\mathrm{Z}_{\mathrm{HER} 2: 342}\right)$, binds albumin independently of $\mathrm{pH}$-dependent binding to FcRn (259). Furthermore, FcRn binding was unaffected by the presence of $\operatorname{IgG}$, and the ABD fusion showed a similar biodistribution profile as rat albumin in wild-type rats (259). Thus, these data strongly indicate that the anti-albumin peptides and ABD bind FcRn properly when fused to a protein of interest. However, this should be addressed in each case as to rule out that the fusion partner causes steric hindrance or otherwise negatively affect FcRn binding. Importantly, to allow efficient FcRn-mediated recycling and transcytosis, the albumin binding molecules need to bind albumin not only at physiological $\mathrm{pH}$ but also at the mildly acidic $\mathrm{pH}$ found within endosomal compartments. The latter was addressed for the albumin binding peptides, where no differences in affinity were detected as a function of $\mathrm{pH}$ (253).

\section{CONCLUDING REMARKS}

The neonatal Fc receptor is a unique cellular receptor with affinity for IgG and albumin, two completely unrelated plasma proteins. Both ligands bind the receptor in a remarkably similar $\mathrm{pH}$-dependent manner, which is fundamental for the versatile functions spanning both immunological and nonimmunological processes. It is broadly expressed and functions in both hematopoietic and non-hematopoietic cells, including specialized cell types of vital organs such as the kidneys, liver, and placenta, which highlight the importance of the receptor in homeostatic regulation of the ligands throughout the body. However, further studies are needed to obtain a more complete understanding of the roles of FcRn at every body site, and also the potential impact of other albumin receptors.

Furthermore, our molecular understanding of how FcRn binds its ligands and controls their half-life has prompted engineering of new classes of IgG molecules with unique blocking and transport properties. The recent elucidation of the FcRn-albumin relationship also offers opportunities for refining existing albumin technologies or development of completely new concepts. Recently, engineered albumin variants with altered FcRn binding kinetics were shown to result in extended serum half-life beyond that of natural albumin. This has triggered enthusiasm as these may be used as fusion partners to gain superior pharmacokinetics of both biotherapeutics and chemical drugs. These findings will surely encourage further molecular engineering of albumin variants with tailored pharmacokinetic properties. Recent knowledge about the FcRn-albumin interaction and its key role in homeostatic regulation will also allow reinterpretation of previously published data on conjugation of payloads, as disruption of the interaction with FcRn will undoubtedly have a major impact on their in vivo behavior. Especially, pre-clinical in vivo studies of human albumin-based therapeutics in mice or rats need to be reassessed since rodent FcRn binds only weakly to human albumin, which will compete poorly for binding to the mouse receptor in the presence of larger amounts of endogenous mouse albumin. Thus, for future studies, there is a great need for new transgenic pre-clinical animal models suitable for studies of human albumin variants and human albumin-based therapeutics.

\section{ACKNOWLEDGMENTS}

This work was supported in part by the Research Council of Norway through its Centres of Excellence funding scheme (project number 179573). Jan Terje Andersen was supported by the Research Council of Norway (Grant no. 230526/F20 and 179573/V40). Kine Marita Knudsen Sand was supported by University of Oslo. Malin Bern was supported by the Research Council of Norway through its program for Global Health and Vaccination Research (GLOBVAC) (Grant no. 143822). Jeannette Nilsen was supported by the Research Council of Norway (230526/F20). We acknowledge Ole J. B. Landsverk for contribution to figures.

\section{REFERENCES}

1. Waldmann TA, Strober W. Metabolism of immunoglobulins. Prog Allergy (1969) 13:1-110.

2. Peters T. Serum albumin. Adv Protein Chem (1985) 37:161-245. doi:10.1016/ S0065-3233(08)60065-0

3. Spiegelberg HL, Fishkin BG. The catabolism of human G immunoglobulins of different heavy chain subclasses. 3. The catabolism of heavy chain disease proteins and of Fc fragments of myeloma proteins. Clin Exp Immunol (1972) 10(4):599-607.

4. Peters T. All about albumin: Biochemistry, Genetics and Medical Applications. San Diego CA: Academic Press (1996). 
5. Kragh-Hansen U, Chuang VT, Otagiri M. Practical aspects of the ligandbinding and enzymatic properties of human serum albumin. Biol Pharm Bull (2002) 25(6):695-704. doi:10.1248/bpb.25.695

6. Fasano M, Curry S, Terreno E, Galliano M, Fanali G, Narciso P, et al. The extraordinary ligand binding properties of human serum albumin. IUBMB Life (2005) 57(12):787-96. doi:10.1080/15216540500404093

7. Brambell FW. The transmission of immunity from mother to young and the catabolism of immunoglobulins. Lancet (1966) 2(7473):1087-93. doi:10.1016/ S0140-6736(66)92190-8

8. Schultze HE, Heremans JF. Molecular biology of human proteins: with special reference to plasma proteins. Nature and Metabolism of Extracellular Proteins, Vol. 1. New York: Elsevier (1966).

9. Israel EJ, Wilsker DF, Hayes KC, Schoenfeld D, Simister NE. Increased clearance of IgG in mice that lack beta 2-microglobulin: possible protective role of FcRn. Immunology (1996) 89(4):573-8. doi:10.1046/j.1365-2567.1996.d01-775.x

10. Junghans RP, Anderson CL. The protection receptor for IgG catabolism is the beta2-microglobulin-containing neonatal intestinal transport receptor. Proc Natl Acad Sci U S A (1996) 93(11):5512-6. doi:10.1073/pnas.93.11.5512

11. Chaudhury C, Mehnaz S, Robinson JM, Hayton WL, Pearl DK, Roopenian DC, et al. The major histocompatibility complex-related Fc receptor for IgG $(\mathrm{FcRn})$ binds albumin and prolongs its lifespan. J Exp Med (2003) 197(3):315-22. doi:10.1084/jem.20021829

12. Wani MA, Haynes LD, Kim J, Bronson CL, Chaudhury C, Mohanty S, et al. Familial hypercatabolic hypoproteinemia caused by deficiency of the neonatal Fc receptor, FcRn, due to a mutant beta2-microglobulin gene. Proc Natl Acad Sci U S A (2006) 103(13):5084-9. doi:10.1073/pnas.0600548103

13. Roopenian D, Akilesh S. FcRn: the neonatal Fc receptor comes of age. Nat Rev Immunol (2007) 7(9):715-25. doi:10.1038/nri2155

14. Sleep D, Cameron J, Evans LR. Albumin as a versatile platform for drug halflife extension. Biochim Biophys Acta (2013) 1830(12):5526-34. doi:10.1016/j. bbagen.2013.04.023

15. Elsadek B, Kratz F. Impact of albumin on drug delivery - new applications on the horizon. J Control Release (2012) 157(1):4-28. doi:10.1016/j.jconrel.2011. 09.069

16. Kratz F. A clinical update of using albumin as a drug vehicle - a commentary. J Control Release (2014) 190:331-6. doi:10.1016/j.jconrel.2014.03.013

17. Andersen JT, Daba MB, Berntzen G, Michaelsen TE, Sandlie I. Cross-species binding analyses of mouse and human neonatal Fc receptor show dramatic differences in immunoglobulin G and albumin binding. J Biol Chem (2010) 285(7):4826-36. doi:10.1074/jbc.M109.081828

18. Andersen JT, Dalhus B, Viuff D, Ravn BT, Gunnarsen KS, Plumridge A, et al. Extending serum half-life of albumin by engineering neonatal Fc receptor (FcRn) binding. J Biol Chem (2014) 289(19):13492-502. doi:10.1074/jbc. M114.549832

19. Yoshida M, Claypool SM, Wagner JS, Mizoguchi E, Mizoguchi A, Roopenian DC, et al. Human neonatal Fc receptor mediates transport of IgG into luminal secretions for delivery of antigens to mucosal dendritic cells. Immunity (2004) 20(6):769-83. doi:10.1016/j.immuni.2004.05.007

20. Dickinson BL, Badizadegan K, Wu Z, Ahouse JC, Zhu X, Simister NE et al. Bidirectional FcRn-dependent IgG transport in a polarized human intestinal epithelial cell line. J Clin Invest (1999) 104(7):903-11. doi:10.1172/ JCI6968

21. Israel EJ, Taylor S, Wu Z, Mizoguchi E, Blumberg RS, Bhan A, et al. Expression of the neonatal Fc receptor, FcRn, on human intestinal epithelial cells. Immunology (1997) 92(1):69-74. doi:10.1046/j.1365-2567.1997.00326.x

22. Simister NE, Story CM, Chen HL, Hunt JS. An IgG-transporting Fc receptor expressed in the syncytiotrophoblast of human placenta. Eur J Immunol (1996) 26(7):1527-31. doi:10.1002/eji.1830260718

23. Spiekermann GM, Finn PW, Ward ES, Dumont J, Dickinson BL, Blumberg RS, et al. Receptor-mediated immunoglobulin $\mathrm{G}$ transport across mucosal barriers in adult life: functional expression of FcRn in the mammalian lung. J Exp Med (2002) 196(3):303-10. doi:10.1084/jem.20020400

24. Firan M, Bawdon R, Radu C, Ober RJ, Eaken D, Antohe F, et al. The MHC class I-related receptor, FcRn, plays an essential role in the maternofetal transfer of gamma-globulin in humans. Int Immunol (2001) 13(8):993-1002. doi:10.1093/intimm/13.8.993

25. Bitonti AJ, Dumont JA, Low SC, Peters RT, Kropp KE, Palombella VJ, et al. Pulmonary delivery of an erythropoietin Fc fusion protein in non-human primates through an immunoglobulin transport pathway. Proc Natl Acad Sci U S A (2004) 101(26):9763-8. doi:10.1073/pnas.0403235101

26. Dumont J, Bitonti A, Clark D, Evans S, Pickford M, Newman S. Delivery of an erythropoietin-Fc fusion protein by inhalation in humans through an immunoglobulin transport pathway. J Aerosol Med (2005) 18(3):294-303. doi:10.1089/jam.2005.18.294

27. Low SC, Nunes SL, Bitonti AJ, Dumont JA. Oral and pulmonary delivery of FSH-Fc fusion proteins via neonatal Fc receptor-mediated transcytosis. Hum Reprod (2005) 20(7):1805-13. doi:10.1093/humrep/deh896

28. Grubb JH, Vogler C, Tan Y, Shah GN, MacRae AF, Sly WS. Infused Fc-tagged beta-glucuronidase crosses the placenta and produces clearance of storage in utero in mucopolysaccharidosis VII mice. Proc Natl Acad Sci U S A (2008) 105(24):8375-80. doi:10.1073/pnas.0803715105

29. Ye L, Zeng R, Bai Y, Roopenian D, Zhu X. Efficient mucosal vaccination mediated by the neonatal Fc receptor. Nat Biotechnol (2011) 29(2):158-63. doi: $10.1038 /$ nbt. 1742

30. Li Z, Palaniyandi S, Zeng R, Tuo W, Roopenian DC, Zhu X. Transfer of IgG in the female genital tract by MHC class I-related neonatal Fc receptor $(\mathrm{FcRn})$ confers protective immunity to vaginal infection. Proc Natl Acad Sci U S A (2011) 108(11):4388-93. doi:10.1073/pnas.1012861108

31. Lu L, Palaniyandi S, Zeng R, Bai Y, Liu X, Wang Y, et al. A neonatal Fc receptortargeted mucosal vaccine strategy effectively induces HIV-1 antigen-specific immunity to genital infection. J Virol (2011) 85(20):10542-53. doi:10.1128/ JVI.05441-11

32. Pridgen E, Alexis F, Kuo T, Levy-Nissenbaum E, Karnik R, Blumberg R, et al. Transepithelial transport of fc-targeted nanoparticles by the neonatal fc receptor for oral delivery. Sci Transl Med (2013) 5(213):213ra167. doi:10.1126/scitranslmed.3007049

33. Brambell FW, Hemmings WA, Oakley CL, Porter RR. The relative transmission of the fractions of papain hydrolyzed homologous gamma-globulin from the uterine cavity to the foetal circulation in the rabbit. Proc R Soc Lond B Biol Sci (1960) 151:478-82. doi:10.1098/rspb.1960.0011

34. Halliday R. Prenatal and postnatal transmission of passive immunity to young rats. Proc R Soc Lond B Biol Sci (1955) 144(916):427-30. doi:10.1098/rspb. 1955.0068

35. Bamford DR. Studies in vitro of the passage of serum proteins across the intestinal wall of young rats. Proc R Soc Lond B Biol Sci (1966) 166(1002):30-45. doi:10.1098/rspb.1966.0083

36. Fahey JL, Robinson AG. Factors controlling serum gamma-globulin concentration. J Exp Med (1963) 118:845-68. doi:10.1084/jem.118.5.845

37. Brambell FW, Hemmings WA, Morris IG. A theoretical model of gammaglobulin catabolism. Nature (1964) 203:1352-4. doi:10.1038/2031352a0

38. Rodewald R. pH-dependent binding of immunoglobulins to intestinal cells of the neonatal rat. J Cell Biol (1976) 71(2):666-9. doi:10.1083/jcb.71.2.666

39. Simister NE, Rees AR. Isolation and characterization of an Fc receptor from neonatal rat small intestine. Eur J Immunol (1985) 15(7):733-8. doi:10.1002/ eji. 1830150718

40. Simister NE, Mostov KE. An Fc receptor structurally related to MHC class I antigens. Nature (1989) 337(6203):184-7. doi:10.1038/337184a0

41. Story CM, Mikulska JE, Simister NE. A major histocompatibility complex class I-like Fc receptor cloned from human placenta: possible role in transfer of immunoglobulin G from mother to fetus. J Exp Med (1994) 180(6):2377-81. doi:10.1084/jem.180.6.2377

42. Zhu X, Meng G, Dickinson B, Li X, Mizoguchi E, Miao L, et al. MHC class I-related neonatal $\mathrm{Fc}$ receptor for IgG is functionally expressed in monocytes, intestinal macrophages, and dendritic cells. J Immunol (2001) 166(5):3266-76. doi:10.4049/jimmunol.166.5.3266

43. Antohe F, Rădulescu L, Gafencu A, Ghetie V, Simionescu M. Expression of functionally active FcRn and the differentiated bidirectional transport of IgG in human placental endothelial cells. Hum Immunol (2001) 62(2):93-105. doi:10.1016/S0198-8859(00)00244-5

44. Powner MB, McKenzie JA, Christianson GJ, Roopenian DC, Fruttiger M. Expression of neonatal Fc receptor in the eye. Invest Ophthalmol Vis Sci (2014) 55(3):1607-15. doi:10.1167/iovs.13-12574

45. van Bilsen K, van Hagen PM, Bastiaans J, van Meurs JC, Missotten T, Kuijpers RW, et al. The neonatal Fc receptor is expressed by human retinal pigment epithelial cells and is downregulated by tumour necrosis factor-alpha. $\mathrm{BrJ}$ Ophthalmol (2011) 95(6):864-8. doi:10.1136/bjo.2010.187930 
46. Haymann JP, Levraud JP, Bouet S, Kappes V, Hagege J, Nguyen G, et al. Characterization and localization of the neonatal Fc receptor in adult human kidney. J Am Soc Nephrol (2000) 11(4):632-9.

47. Cianga P, Cianga C, Cozma L, Ward ES, Carasevici E. The MHC class I related Fc receptor, FcRn, is expressed in the epithelial cells of the human mammary gland. Hum Immunol (2003) 64(12):1152-9. doi:10.1016/j.humimm.2003.08. 025

48. Cauza K, Hinterhuber G, Dingelmaier-Hovorka R, Brugger K, Klosner G, Horvat R, et al. Expression of FcRn, the MHC class I-related receptor for IgG, in human keratinocytes. J Invest Dermatol (2005) 124(1):132-9. doi:10.1111/j. 0022-202X.2004.23542.x

49. Akilesh S, Christianson GJ. Neonatal FcR expression in bone marrow-derived cells functions to protect serum IgG from catabolism. J Immunol (2007) 179(7):4580-88. doi:10.4049/jimmunol.179.7.4580

50. Akilesh S, Huber TB, Wu H, Wang G, Hartleben B, Kopp JB, et al. Podocytes use FcRn to clear IgG from the glomerular basement membrane. Proc Natl Acad Sci U S A (2008) 105(3):967-72. doi:10.1073/pnas.0711515105

51. Montoyo HP, Vaccaro C, Hafner M, Ober RJ, Mueller W, Ward ES. Conditional deletion of the MHC class I-related receptor FcRn reveals the sites of IgG homeostasis in mice. Proc Natl Acad Sci U S A (2009) 106(8):2788-93. doi:10.1073/pnas.0810796106

52. Kim H, Fariss RN, Zhang C, Robinson SB, Thill M, Csaky KG. Mapping of the neonatal Fc receptor in the rodent eye. Invest Ophthalmol Vis Sci (2008) 49(5):2025-9. doi:10.1167/iovs.07-0871

53. Blumberg RS, Koss T, Story CM. A major histocompatibility complex class I-related Fc receptor for IgG on rat hepatocytes. J Clin Invest (1995) 95(5):2397-402. doi:10.1172/JCI117934

54. Brambell FW. The Transmission of Passive Immunity from Mother to Young. Amsterdam: North Holland Publishing Company (1970).

55. Anderson C, Chaudhury C, Kim J, Bronson C, Wani M, Mohanty S. Perspective $-\mathrm{FcRn}$ transports albumin: relevance to immunology and medicine. Trends Immunol (2006) 27(7):343-8. doi:10.1016/j.it.2006.05.004

56. Andersen JT, Dee Qian J, Sandlie I. The conserved histidine 166 residue of the human neonatal Fc receptor heavy chain is critical for the $\mathrm{pH}$-dependent binding to albumin. Eur J Immunol (2006) 36(11):3044-51. doi:10.1002/eji. 200636556

57. Chaudhury C, Brooks CL, Carter DC, Robinson JM, Anderson CL. Albumin binding to FcRn: distinct from the FcRn-IgG interaction. Biochemistry (2006) 45(15):4983-90. doi:10.1021/bi052628y

58. Ghetie V, Hubbard JG, Kim JK, Tsen MF, Lee Y, Ward ES. Abnormally short serum half-lives of IgG in beta 2-microglobulin-deficient mice. Eur J Immunol (1996) 26(3):690-6. doi:10.1002/eji.1830260327

59. Vaughn DE, Bjorkman PJ. Structural basis of $\mathrm{pH}$-dependent antibody binding by the neonatal Fc receptor. Structure (1998) 6(1):63-73. doi:10.1016/S09692126(98)00008-2

60. West A, Bjorkman P. Crystal structure and immunoglobulin G binding properties of the human major histocompatibility complex-related $F_{c}$ receptor(,). Biochemistry (2000) 39(32):9698-708. doi:10.1021/bi000749m

61. Mezo AR, Sridhar V, Badger J, Sakorafas P, Nienaber V. X-ray crystal structures of monomeric and dimeric peptide inhibitors in complex with the human neonatal Fc receptor, FcRn. J Biol Chem (2010) 285(36):27694-701. doi:10.1074/jbc.m110.120667

62. Burmeister W, Gastinel L, Simister N, Blum M, Bjorkman P. Crystal structure at 2.2 A resolution of the MHC-related neonatal Fc receptor. Nature (1994) 372(6504):336-43. doi:10.1038/372336a0

63. Gastinel LN, Simister NE, Bjorkman PJ. Expression and crystallization of a soluble and functional form of an Fc receptor related to class I histocompatibility molecules. Proc Natl Acad Sci U S A (1992) 89(2):638-42. doi:10.1073/pnas.89.2.638

64. Burmeister W, Huber A, Bjorkman P. Crystal structure of the complex of rat neonatal Fc receptor with Fc. Nature (1994) 372(6504):379-83. doi:10.1038/ $372379 \mathrm{a} 0$

65. Martin WL, West AP, Gan L, Bjorkman PJ. Crystal structure at 2.8 A of an FcRn/heterodimeric Fc complex: mechanism of pH-dependent binding. Mol Cell (2001) 7(4):867-77. doi:10.1016/S1097-2765(01)00230-1

66. Praetor A, Hunziker W. beta(2)-Microglobulin is important for cell surface expression and pH-dependent IgG binding of human FcRn. J Cell Sci (2002) 115(Pt 11):2389-97.
67. Zhu X, Peng J, Raychowdhury R, Nakajima A, Lencer W, Blumberg R. The heavy chain of neonatal $\mathrm{Fc}$ receptor for $\mathrm{IgG}$ is sequestered in endoplasmic reticulum by forming oligomers in the absence of beta2-microglobulin association. Biochem J (2002) 367(Pt 3):703-14. doi:10.1042/BJ20020200

68. Zhu X, Peng J, Chen D, Liu X, Ye L, Iijima H, et al. Calnexin and ERp57 facilitate the assembly of the neonatal Fc receptor for IgG with beta 2microglobulin in the endoplasmic reticulum. JImmunol (2005) 175(2):967-76. doi:10.4049/jimmunol.175.2.967

69. Oganesyan V, Damschroder MM, Cook KE, Li Q, Gao C, Wu H, et al. Structural insights into neonatal Fc receptor-based recycling mechanisms. J Biol Chem (2014) 289(11):7812-24. doi:10.1074/jbc.M113.537563

70. Andersen JT, Dalhus B, Cameron J, Daba MB, Plumridge A, Evans L, et al. Structure-based mutagenesis reveals the albumin-binding site of the neonatal Fc receptor. Nat Commun (2012) 3:610. doi:10.1038/ncomms1607

71. Kuo T, de Muinck E, Claypool S, Yoshida M, Nagaishi T, Aveson V, et al. N-glycan moieties in neonatal Fc receptor determine steady-state membrane distribution and directional transport of IgG. J Biol Chem (2009) 284(13):8292-300. doi:10.1074/jbc.M805877200

72. Schmidt MM, Townson SA, Andreucci AJ, King BM, Schirmer EB, Murillo AJ, et al. Crystal structure of an HSA/FcRn complex reveals recycling by competitive mimicry of HSA ligands at a $\mathrm{pH}$-dependent hydrophobic interface. Structure (2013) 21(11):1966-78. doi:10.1016/j.str.2013.08.022

73. Wu Z, Simister NE. Tryptophan- and dileucine-based endocytosis signals in the neonatal Fc receptor. J Biol Chem (2001) 276(7):5240-7. doi:10.1074/jbc. M006684200

74. Wernick NL, Haucke V, Simister NE. Recognition of the tryptophan-based endocytosis signal in the neonatal Fc receptor by the mu subunit of adaptor protein-2. J Biol Chem (2005) 280(8):7309-16. doi:10.1074/jbc. M410752200

75. Claypool SM, Dickinson BL, Wagner JS. Bidirectional transepithelial IgG transport by a strongly polarized basolateral membrane Fc $\gamma$-receptor. $\mathrm{Mol}$ Biol Cell (2004) 15(4):1746-59. doi:10.1091/mbc.E03-11-0832

76. McCarthy KM, Lam M, Subramanian L, Shakya R, Wu Z, Newton EE, et al. Effects of mutations in potential phosphorylation sites on transcytosis of FcRn. J Cell Sci (2001) 114(Pt 8):1591-8.

77. Ramalingam TS, Detmer SA, Martin WL, Bjorkman PJ. IgG transcytosis and recycling by $\mathrm{FcRn}$ expressed in MDCK cells reveals ligand-induced redistribution. EMBO J (2002) 21(4):590-601. doi:10.1093/emboj/21.4.590

78. Tesar D, Tiangco N, Bjorkman P. Ligand valency affects transcytosis, recycling and intracellular trafficking mediated by the neonatal Fc receptor. Traffic (2006) 7(9):1127-42. doi:10.1111/j.1600-0854.2006.00457.x

79. Leitner K, Ellinger I, Grill M, Brabec M, Fuchs R. Efficient apical IgG recycling and apical-to-basolateral transcytosis in polarized BeWo cells overexpressing hFcRn. Placenta (2006) 27(8):799-811. doi:10.1016/j.placenta.2005.08.008

80. Dickinson BL, Claypool SM, D'Angelo JA, Aiken ML, Venu N, Yen EH, et al. Ca2+-dependent calmodulin binding to FcRn affects immunoglobulin G transport in the transcytotic pathway. Mol Biol Cell (2008) 19(1):414-23. doi:10.1091/mbc.E07-07-0658

81. McMahon HT, Gallop JL. Membrane curvature and mechanisms of dynamic cell membrane remodelling. Nature (2005) 438(7068):590-6. doi:10.1038/ nature 04396

82. He XM, Carter DC. Atomic structure and chemistry of human serum albumin. Nature (1992) 358(6383):209-15. doi:10.1038/358209a0

83. Sugio S, Kashima A, Mochizuki S, Noda M, Kobayashi K. Crystal structure of human serum albumin at 2.5 A resolution. Protein Eng (1999) 12(6):439-46. doi:10.1093/protein/12.6.439

84. Curry S, Mandelkow H, Brick P, Franks N. Crystal structure of human serum albumin complexed with fatty acid reveals an asymmetric distribution of binding sites. Nat Struct Biol (1998) 5(9):827-35. doi:10.1038/1869

85. Dockal M, Carter DC, Rüker F. The three recombinant domains of human serum albumin. Structural characterization and ligand binding properties. $J$ Biol Chem (1999) 274(41):29303-10. doi:10.1074/jbc.274.41.29303

86. Curry S. Lessons from the crystallographic analysis of small molecule binding to human serum albumin. Drug Metab Pharmacokinet (2009) 24(4):342-57. doi:10.2133/dmpk.24.342

87. Bhattacharya AA, Grüne T, Curry S. Crystallographic analysis reveals common modes of binding of medium and long-chain fatty acids to human serum albumin. J Mol Biol (2000) 303(5):721-32. doi:10.1006/jmbi.2000.4158 
88. Sand KM, Dalhus B, Christianson GJ, Bern M, Foss S, Cameron J, et al. Dissection of the neonatal $\mathrm{Fc}$ receptor $(\mathrm{FcRn})$-albumin interface using mutagenesis and anti-FcRn albumin-blocking antibodies. J Biol Chem (2014) 289(24):17228-39. doi:10.1074/jbc.M113.522565

89. Andersen JT, Daba MB, Sandlie I. FcRn binding properties of an abnormal truncated analbuminemic albumin variant. Clin Biochem (2010) 43(4-5):367-72. doi:10.1016/j.clinbiochem.2009.12.001

90. Sand KM, Bern M, Nilsen J, Dalhus B, Gunnarsen KS, Cameron J, et al. Interaction with both domain I and III of albumin is required for optimal $\mathrm{pH}$ dependent binding to the neonatal Fc Receptor (FcRn). J Biol Chem (2014) 289(50):34583-94. doi:10.1074/jbc.M114.587675

91. Petitpas I, Grune T, Bhattacharya AA, Curry S. Crystal structures of human serum albumin complexed with monounsaturated and polyunsaturated fatty acids. J Mol Biol (2001) 314(5):955-60. doi:10.1006/jmbi.2000.5208

92. Fanali G, di Masi A, Trezza V, Marino M, Fasano M, Ascenzi P. Human serum albumin: from bench to bedside. Mol Aspects Med (2012) 33(3):209-90. doi:10.1016/j.mam.2011.12.002

93. Fujiwara S, Amisaki T. Fatty acid binding to serum albumin: molecular simulation approaches. Biochim Biophys Acta (2013) 1830(12):5427-34. doi:10.1016/ j.bbagen.2013.03.032

94. Fujiwara S-I, Amisaki T. Steric and allosteric effects of fatty acids on the binding of warfarin to human serum albumin revealed by molecular dynamics and free energy calculations. Chem Pharm Bull (2011) 59(7):860-7. doi:10.1248/cpb.59.860

95. Fujiwara S-I, Amisaki T. Molecular dynamics study of conformational changes in human serum albumin by binding of fatty acids. Proteins (2006) 64(3):730-9. doi:10.1002/prot.21053

96. Anguizola JA, Basiaga SB, Hage DS. Effects of fatty acids and glycation on drug interactions with human serum albumin. Curr Metabolomics (2013) 1(3):239-50. doi:10.2174/2213235X1130100005

97. Torres MJ, Turell L, Botti H, Antmann L, Carballal S, Ferrer-Sueta G, et al. Modulation of the reactivity of the thiol of human serum albumin and its sulfenic derivative by fatty acids. Arch Biochem Biophys (2012) 521(12):102-10. doi:10.1016/j.abb.2012.03.011

98. Barnett JP, Blindauer CA, Kassaar O, Khazaipoul S, Martin EM, Sadler PJ, et al. Allosteric modulation of zinc speciation by fatty acids. Biochim Biophys Acta (2013) 1830(12):5456-64. doi:10.1016/j.bbagen.2013.05.028

99. Jovanović VB, Pavićević ID, Takić MM, Penezić-Romanjuk AZ, Aćimović JM, Mandić LM. The influence of fatty acids on determination of human serum albumin thiol group. Anal Biochem (2014) 448:50-7. doi:10.1016/j.ab. 2013.11.030

100. Fujiwara S, Amisaki T. Identification of high affinity fatty acid binding sites on human serum albumin by MM-PBSA method. Biophys J (2008) 94(1):95-103. doi:10.1529/biophysj.107.111377

101. Ishima Y, Kragh-Hansen U, Maruyama T, Otagiri M. Albumin as a nitric oxidetraffic protein: characterization, biochemistry and possible future therapeutic applications. Drug Metab Pharmacokinet (2009) 24(4):308-17. doi:10.2133/ dmpk.24.308

102. Bal W, Sokołowska M, Kurowska E, Faller P. Binding of transition metal ions to albumin: sites, affinities and rates. Biochim Biophys Acta (2013) 1830(12):5444-55. doi:10.1016/j.bbagen.2013.06.018

103. Roopenian DC, Christianson GJ, Sproule TJ, Brown AC, Akilesh S, Jung N, et al. The MHC class I-like IgG receptor controls perinatal IgG transport, IgG homeostasis, and fate of IgG-Fc-coupled drugs. J Immunol (2003) 170(7):3528-33. doi:10.4049/jimmunol.170.7.3528

104. Waldmann T, Terry W. Familial hypercatabolic hypoproteinemia. A disorder of endogenous catabolism of albumin and immunoglobulin. J Clin Invest (1990) 86(6):2093-8. doi:10.1172/JCI114947

105. Kim J, Bronson C, Hayton W, Radmacher M, Roopenian D, Robinson J, et al. Albumin turnover: FcRn-mediated recycling saves as much albumin from degradation as the liver produces. Am J Physiol Gastrointest Liver Physiol (2006) 290(2):60. doi:10.1152/ajpgi.00286.2005

106. Gordon RS. Idiopathic hypoalbuminemias: clinical staff conference at the National Institutes of Health. Ann Intern Med (1959) 51(3):553-76. doi:10. 7326/0003-4819-51-3-553

107. Bennhold H, Kallee E. Comparative studies on the half-life of I 131-labeled albumins and nonradioactive human serum albumin in a case of analbuminemia. J Clin Invest (1959) 38(5):863-72. doi:10.1172/JCI103868
108. Cormode EJ, Lyster DM, Israels S. Analbuminemia in a neonate. J Pediatr (1975) 86(6):862-7. doi:10.1016/S0022-3476(75)80215-0

109. Nagase S, Shimamune K, Shumiya S. Albumin-deficient rat mutant. Science (1979) 205(4406):590-1. doi:10.1126/science.451621

110. Nagase S, Shimamune K, Shumiya S. Albumin-deficient rat mutant: an animal model for analbuminemia. Jikken Dobutsu (1980) 29(1):33-8.

111. Minchiotti L, Galliano M, Kragh-Hansen U, Peters T Jr. Mutations and polymorphisms of the gene of the major human blood protein, serum albumin. Hum Mutat (2008) 29(8):1007-16. doi:10.1002/humu.20754

112. Kragh-Hansen U, Minchiotti L, Galliano M, Peters T. Human serum albumin isoforms: genetic and molecular aspects and functional consequences. Biochim Biophys Acta (2013) 1830(12):5405-17. doi:10.1016/j.bbagen.2013.03.026

113. Arques S, Ambrosi P. Human serum albumin in the clinical syndrome of heart failure. J Card Fail (2011) 17(6):451-8. doi:10.1016/j.cardfail.2011.02.010

114. Asher V, Lee J, Bali A. Preoperative serum albumin is an independent prognostic predictor of survival in ovarian cancer. Med Oncol (2012) 29(3):2005-9. doi:10.1007/s12032-011-0019-5

115. Takata Y, Ansai T, Yoshihara A, Miyazaki H. Serum albumin (SA) levels and 10year mortality in a community-dwelling 70-year-old population. Arch Gerontol Geriatr (2012) 54(1):39-43. doi:10.1016/j.archger.2011.02.018

116. Filippatos GS, Desai RV, Ahmed MI. Hypoalbuminaemia and incident heart failure in older adults. Eur J Heart Fail (2011) 13(10):1078-86. doi:10.1093/ eurjhf/hfr088

117. Borg N, Guilfoyle MR, Greenberg DC, Watts C. Serum albumin and survival in glioblastoma multiforme. J Neurooncol (2011) 105(1):77-81. doi:10.1007/ s11060-011-0562-0

118. Peach R, Brennan S. Structural characterization of a glycoprotein variant of human serum albumin: albumin Casebrook (494 Asp - - Asn). Biochim Biophys Acta (1991) 1097(1):49-54. doi:10.1016/0925-4439(91)90023-3

119. Sheffield WP, Marques JA, Bhakta V, Smith IJ. Modulation of clearance of recombinant serum albumin by either glycosylation or truncation. Thromb Res (2000) 99(6):613-21. doi:10.1016/S0049-3848(00)00286-3

120. Dolcini L, Caridi G, Dagnino M, Sala A, Gokce S, Sokucu S, et al. Analbuminemia produced by a novel splicing mutation. Clin Chem (2007) 53(8):1549-52. doi:10.1373/clinchem.2007.089748

121. Minchiotti L, Campagnoli M, Rossi A, Cosulich ME, Monti M, Pucci P, et al. A nucleotide insertion and frameshift cause albumin Kénitra, an extended and O-glycosylated mutant of human serum albumin with two additional disulfide bridges. Eur J Biochem (2001) 268(2):344-52. doi:10.1046/j.1432-1033.2001. 01899.x

122. Andersen JT, Sandlie I. A receptor-mediated mechanism to support clinical observation of altered albumin variants. Clin Chem (2007) 53(12):2216. doi:10.1373/clinchem.2007.097071

123. Gan Z, Ram S, Ober RJ, Ward ES. Using multifocal plane microscopy to reveal novel trafficking processes in the recycling pathway. J Cell Sci (2013) 126(Pt 5):1176-88. doi:10.1242/jcs.116327

124. Ober RJ, Martinez C, Vaccaro C, Zhou J, Ward ES. Visualizing the site and dynamics of IgG salvage by the MHC class I-related receptor, FcRn. J Immunol (2004) 172(4):2021-9. doi:10.4049/jimmunol.172.4.2021

125. Ober RJ, Martinez C, Lai X, Zhou J, Ward ES. Exocytosis of IgG as mediated by the receptor, FcRn: an analysis at the single-molecule level. Proc Natl Acad Sci US A (2004) 101(30):11076-81. doi:10.1073/pnas.0402970101

126. Ward ES, Zhou J, Ghetie V, Ober RJ. Evidence to support the cellular mechanism involved in serum IgG homeostasis in humans. Int Immunol (2003) 15(2):187-95. doi:10.1093/intimm/dxg018

127. Ward ES, Martinez C, Vaccaro C, Zhou J, Tang Q, Ober RJ. From sorting endosomes to exocytosis: association of Rab4 and Rab11 GTPases with the Fc receptor, FcRn, during recycling. Mol Biol Cell (2005) 16(4):2028-38. doi:10.1091/mbc.E04-08-0735

128. Prabhat P, Gan Z, Chao J, Ram S, Vaccaro C, Gibbons S, et al. Elucidation of intracellular recycling pathways leading to exocytosis of the $\mathrm{Fc}$ receptor FcRn, by using multifocal plane microscopy. Proc Natl Acad Sci U S A (2007) 104(14):5889-94. doi:10.1073/pnas.0700337104

129. Stenmark H. Rab GTPases as coordinators of vesicle traffic. Nat Rev Mol Cell Biol (2009) 10(8):513-25. doi:10.1038/nrm2728

130. Rink J, Ghigo E, Kalaidzidis Y, Zerial M. Rab conversion as a mechanism of progression from early to late endosomes. Cell (2005) 122(5):735-49. doi:10.1016/j.cell.2005.06.043 
131. Mezo AR, McDonnell KA, Castro A, Fraley C. Structure-activity relationships of a peptide inhibitor of the human FcRn:human IgG interaction. Bioorg Med Chem (2008) 16(12):6394-405. doi:10.1016/j.bmc.2008.05.004

132. Mezo AR, McDonnell KA, Hehir CA, Low SC, Palombella VJ, Stattel JM, et al. Reduction of IgG in nonhuman primates by a peptide antagonist of the neonatal Fc receptor FcRn. Proc Natl Acad Sci U S A (2008) 105(7):2337-42. doi:10.1073/pnas.0708960105

133. Liu X, Ye L, Bai Y, Mojidi H, Simister NE, Zhu X. Activation of the JAK/STAT1 signaling pathway by IFN-gamma can down-regulate functional expression of the MHC class I-related neonatal Fc receptor for IgG. J Immunol (2008) 181(1):449-63. doi:10.4049/jimmunol.181.1.449

134. Liu X, Ye L, Christianson GJ, Yang J-QQ, Roopenian DC, Zhu X. NF-kappaB signaling regulates functional expression of the MHC class I-related neonatal Fc receptor for IgG via intronic binding sequences. J Immunol (2007) 179(5):2999-3011. doi:10.4049/jimmunol.179.5.2999

135. Abrahamson DR, Powers A, Rodewald R. Intestinal absorption of immune complexes by neonatal rats: a route of antigen transfer from mother to young. Science (1979) 206(4418):567-9. doi:10.1126/science.493961

136. Wallace KH, Rees AR. Studies on the immunoglobulin-G Fc-fragment receptor from neonatal rat small intestine. Biochem J (1980) 188(1):9-16.

137. Rodewald R, Abrahamson DR. Receptor-mediated transport of IgG across the intestinal epithelium of the neonatal rat. Ciba Found Symp (1982) 92:209-32.

138. Gill RK, Mahmood S, Sodhi CP, Nagpaul JP, Mahmood A. IgG binding and expression of its receptor in rat intestine during postnatal development. Indian J Biochem Biophys (1999) 36(4):252-7.

139. Shah U, Dickinson BL, Blumberg RS, Simister NE, Lencer WI, Walker WA. Distribution of the IgG Fc receptor, FcRn, in the human fetal intestine. Pediatr Res (2003) 53(2):295-301. doi:10.1203/01.PDR.0000047663.81816.E3

140. Hornby P, Cooper P, Kliwinski C, Ragwan E, Mabus J, Harman B, et al. Human and non-human primate intestinal FcRn expression and immunoglobulin G transcytosis. Pharm Res (2013) 31(4):908-22. doi:10.1007/s11095-013-1212-3

141. Yoshida M, Masuda A, Kuo TT, Kobayashi K. IgG transport across mucosal barriers by neonatal Fc receptor for IgG and mucosal immunity. Springer Semin Immunopathol (2006) 28(4):397-403. doi:10.1007/s00281-006-0054-Z

142. Tzaban S, Massol RH, Yen E, Hamman W. The recycling and transcytotic pathways for IgG transport by FcRn are distinct and display an inherent polarity. $J$ Cell Biol (2009) 185(4):673-84. doi:10.1083/jcb.200809122

143. Johansen FE, Pekna M, Norderhaug IN, Haneberg B, Hietala MA, Krajci P, et al. Absence of epithelial immunoglobulin A transport, with increased mucosal leakiness, in polymeric immunoglobulin receptor/secretory componentdeficient mice. J Exp Med (1999) 190(7):915-22. doi:10.1084/jem.190.7.915

144. Kitz R, Ahrens P, Zielen S. Immunoglobulin levels in bronchoalveolar lavage fluid of children with chronic chest disease. Pediatr Pulmonol (2000) 29(6):443-51. doi:10.1002/(SICI)1099-0496(200006)29:6<443::AIDPPUL6>3.0.CO;2-M

145. Suh JH, Miner JH. The glomerular basement membrane as a barrier to albumin. Nat Rev Nephrol (2013) 9(8):470-7. doi:10.1038/nrneph.2013.109

146. Dobrinskikh E, Okamura K, Kopp JB, Doctor RB, Blaine J. Human podocytes perform polarized, caveolae-dependent albumin endocytosis. Am J Physiol Renal Physiol (2014) 306(9):51. doi:10.1152/ajprenal.00532.2013

147. Birn H, Christensen EI. Renal albumin absorption in physiology and pathology. Kidney Int (2006) 69(3):440-9. doi:10.1038/sj.ki.5000141

148. Kobayashi N, Suzuki Y, Tsuge T, Okumura K, Ra C, Tomino Y. FcRn-mediated transcytosis of immunoglobulin $\mathrm{G}$ in human renal proximal tubular epithelial cells. Am J Physiol Renal Physiol (2002) 282(2):65. doi:10.1152/ajprenal.0164. 2001

149. Tenten V, Menzel S, Kunter U, Sicking E-MM, van Roeyen CR, Sanden SK, et al. Albumin is recycled from the primary urine by tubular transcytosis. J Am Soc Nephrol (2013) 24(12):1966-80. doi:10.1681/asn.2013010018

150. Sarav M, Wang Y, Hack BK, Chang A, Jensen M, Bao L, et al. Renal FcRn reclaims albumin but facilitates elimination of IgG. J Am Soc Nephrol (2009) 20(9):1941-52. doi:10.1681/ASN.2008090976

151. Aseem O, Smith BT, Cooley MA, Wilkerson BA, Argraves KM, Remaley AT, et al. Cubilin maintains blood levels of HDL and albumin. J Am Soc Nephrol (2013) 25(5):1028-36. doi:10.1681/ASN.2013060671

152. Amsellem S, Gburek J, Hamard G, Nielsen R, Willnow TE, Devuyst O, et al. Cubilin is essential for albumin reabsorption in the renal proximal tubule. $J$ Am Soc Nephrol (2010) 21(11):1859-67. doi:10.1681/ASN.2010050492
153. Birn H, Fyfe JC, Jacobsen C, Mounier F, Verroust PJ, Orskov H, et al. Cubilin is an albumin binding protein important for renal tubular albumin reabsorption. J Clin Invest (2000) 105(10):1353-61. doi:10.1172/JCI8862

154. Cui S, Verroust PJ, Moestrup SK, Christensen EI. Megalin/gp330 mediates uptake of albumin in renal proximal tubule. Am J Physiol (1996) 271(4 Pt 2):7.

155. Moestrup SK, Kozyraki R, Kristiansen M, Kaysen JH, Rasmussen HH, Brault $\mathrm{D}$, et al. The intrinsic factor-vitamin B12 receptor and target of teratogenic antibodies is a megalin-binding peripheral membrane protein with homology to developmental proteins. J Biol Chem (1998) 273(9):5235-42. doi:10.1074/jbc.273.9.5235

156. Storm T, Tranebjaerg L, Frykholm C, Birn H, Verroust PJ, Neveus T, et al. Renal phenotypic investigations of megalin-deficient patients: novel insights into tubular proteinuria and albumin filtration. Nephrol Dial Transplant (2013) 28(3):585-91. doi:10.1093/ndt/gfs462

157. Treyer A, Müsch A. Hepatocyte polarity. Compr Physiol (2013) 3:243-87. doi:10.1002/cphy.c120009

158. Orlans E, Peppard JV, Payne AW, Fitzharris BM, Mullock BM, Hinton RH, et al. Comparative aspects of the hepatobiliary transport of IgA. Ann N Y Acad Sci (1983) 409:411-27. doi:10.1111/j.1749-6632.1983.tb26886.x

159. Dive C, Nadalini RA, Vaerman JP, Heremans JF. Origin and nature of the proteins of bile. II. A comparative analysis of serum, hepatic lymph and bile proteins in the dog. Eur J Clin Invest (1974) 4(4):241-6. doi:10.1111/j.13652362.1974.tb02340.x

160. Telleman P, Junghans R. The role of the Brambell receptor (FcRB) in liver: protection of endocytosed immunoglobulin G (IgG) from catabolism in hepatocytes rather than transport of IgG to bile. Immunology (2000) 100(2):245-51. doi:10.1046/j.1365-2567.2000.00034.x

161. Borvak J, Richardson J, Medesan C, Antohe F, Radu C, Simionescu M, et al. Functional expression of the MHC class I-related receptor, FcRn, in endothelial cells of mice. Int Immunol (1998) 10(9):1289-98. doi:10.1093/intimm/10. 9.1289

162. Qiao S-W, Kobayashi K, Johansen F-E, Sollid L, Andersen J, Milford E, et al. Dependence of antibody-mediated presentation of antigen on FcRn. Proc Natl Acad Sci U S A (2008) 105(27):9337-42. doi:10.1073/pnas.0801717105

163. Baker K, Qiao SW, Kuo TT, Aveson VG, Platzer B, Andersen JT, et al. Neonatal Fc receptor for IgG (FcRn) regulates cross-presentation of IgG immune complexes by CD8-CD11b+ dendritic cells. Proc Natl Acad Sci U S A (2011) 108(24):9927-32. doi:10.1073/pnas.1019037108

164. Baker K, Rath T, Flak MB, Arthur JC, Chen Z, Glickman JN, et al. Neonatal Fc receptor expression in dendritic cells mediates protective immunity against colorectal cancer. Immunity (2013) 39(6):1095-107. doi:10.1016/j.immuni.2013. 11.003

165. Baker K, Rath T, Pyzik M, Blumberg RS. The role of FcRn in antigen presentation. Front Immunol (2014) 5:408. doi:10.3389/fimmu.2014.00408

166. Landsverk OJ, Bakke O, Gregers TF. MHC II and the endocytic pathway: regulation by invariant chain. Scand J Immunol (2009) 70(3):184-93. doi:10.1111/j.1365-3083.2009.02301.x

167. Blum JS, Wearsch PA, Cresswell P. Pathways of antigen processing. Annu Rev Immunol (2013) 31:443-73. doi:10.1146/annurev-immunol-032712095910

168. Ye L, Liu X, Rout SN, Li Z, Yan Y, Lu L, et al. The MHC class II-associated invariant chain interacts with the neonatal Fc gamma receptor and modulates its trafficking to endosomal/lysosomal compartments. J Immunol (2008) 181(4):2572-85. doi:10.4049/jimmunol.181.4.2572

169. Liu H, Moynihan KD, Zheng Y, Szeto GL, Li AV, Huang B, et al. Structure-based programming of lymph-node targeting in molecular vaccines. Nature (2014) 507(7493):519-22. doi:10.1038/nature12978

170. Schlachetzki F, Zhu C, Pardridge WM. Expression of the neonatal Fc receptor (FcRn) at the blood-brain barrier. J Neurochem (2002) 81(1):203-6. doi:10.1046/j.1471-4159.2002.00840.x

171. Zhang Y, Pardridge WM. Mediated efflux of IgG molecules from brain to blood across the blood-brain barrier. J Neuroimmunol (2001) 114(1-2):168-72. doi:10.1016/S0165-5728(01)00242-9

172. Cooper PR, Ciambrone GJ, Kliwinski CM, Maze E, Johnson L, Li Q, et al. Efflux of monoclonal antibodies from rat brain by neonatal Fc receptor, FcRn. Brain Res (2013) 1534:13-21. doi:10.1016/j.brainres.2013.08.035

173. Deane R, Sagare A, Hamm K, Parisi M, LaRue B, Guo H, et al. IgGassisted age-dependent clearance of Alzheimer's amyloid beta peptide by the 
blood-brain barrier neonatal Fc receptor. J Neurosci (2005) 25(50):11495-503. doi:10.1523/JNEUROSCI.3697-05.2005

174. Garg A, Balthasar JP. Investigation of the influence of FcRn on the distribution of IgG to the brain. AAPS J (2009) 11(3):553-7. doi:10.1208/s12248-0099129-9

175. Abuqayyas L, Balthasar J. Investigation of the role of $F c \gamma R$ and FcRn in mAb distribution to the brain. Mol Pharm (2013) 10(5):1505-13. doi:10.1021/ mp300214k

176. Kim H, Robinson SB, Csaky KG. FcRn receptor-mediated pharmacokinetics of therapeutic IgG in the eye. Mol Vis (2009) 15:2803-12.

177. Leach JL, Sedmak DD, Osborne JM, Rahill B, Lairmore MD, Anderson CL. Isolation from human placenta of the IgG transporter, FcRn, and localization to the syncytiotrophoblast: implications for maternal-fetal antibody transport. J Immunol (1996) 157(8):3317-22.

178. Lyden TW, Robinson JM, Tridandapani S, Teillaud JL, Garber SA, Osborne $\mathrm{JM}$, et al. The $\mathrm{Fc}$ receptor for IgG expressed in the villus endothelium of human placenta is Fc gamma RIIb2. J Immunol (2001) 166(6):3882-9. doi:10.4049/jimmunol.166.6.3882

179. Takizawa T, Anderson CL, Robinson JM. A novel Fc gamma R-defined, IgG-containing organelle in placental endothelium. J Immunol (2005) 175(4):2331-9. doi:10.4049/jimmunol.175.4.2331

180. Kim J, Mohanty S, Ganesan LP, Hua K, Jarjoura D, Hayton WL, et al. FcRn in the yolk sac endoderm of mouse is required for $\operatorname{IgG}$ transport to fetus. $J$ Immunol (2009) 182(5):2583-9. doi:10.4049/jimmunol.0803247

181. Mohanty S, Kim J, Ganesan LP, Phillips GS, Hua K, Jarjoura D, et al. IgG is transported across the mouse yolk sac independently of FcgammaRIIb. $J$ Reprod Immunol (2010) 84(2):133-44. doi:10.1016/j.jri.2009.10.008

182. Vaccaro C, Bawdon R, Wanjie S, Ober RJ, Ward ES. Divergent activities of an engineered antibody in murine and human systems have implications for therapeutic antibodies. Proc Natl Acad Sci U S A (2006) 103(49):18709-14. doi:10.1073/pnas.0606304103

183. Whipple GH, Hill RB, Terry R, Lucas FV, Yuile CL. The placenta and protein metabolism; transfer studies using carbon 14-labeled proteins in dogs. J Exp Med (1955) 101(6):617-26. doi:10.1084/jem.101.6.617

184. Hagerman DD, Villee CA. Transport functions of the placenta. Physiol Rev (1960) 40:313-30.

185. Knobel DP, Michie D. Experiments on the maternal-foetal barrier in the mouse. II. A test for the transmission of maternal serum albumin into the foetal circulation following X-irradiation. J Embryol Exp Morphol (1961) 9:623-7.

186. Bangham DR, Hobbs KR, Terry RJ. Selective placental transfer of serumproteins in the rhesus. Lancet (1958) 2(7042):351-4. doi:10.1016/S01406736(58)90264-2

187. Kulangara AC, Schechtman AM. Passage of heterologous serum proteins from mother into fetal compartments in the rabbit. Am J Physiol (1962) 203:1071-80.

188. Kulangara AC, Schjeide OA. Foetal synthesis and transplacental passage of homologous serum proteins in the rabbit. Nature (1962) 195:811-2. doi:10. $1038 / 195811 \mathrm{a} 0$

189. Gitlin D, Kumate J, Urrusti J, Morales C. The selectivity of the human placenta in the transfer of plasma proteins from mother to fetus. J Clin Invest (1964) 43(10):1938-51. doi:10.1172/JCI105068

190. Burke KA, Jauniaux E, Burton GJ, Cindrova-Davies T. Expression and immunolocalisation of the endocytic receptors megalin and cubilin in the human yolk sac and placenta across gestation. Placenta (2013) 34(11):1105-9. doi:10.1016/j.placenta.2013.08.003

191. Lambot N, Lybaert P, Boom A, Delogne-Desnoeck J, Vanbellinghen AM, Graff G, et al. Evidence for a clathrin-mediated recycling of albumin in human term placenta. Biol Reprod (2006) 75(1):90-7. doi:10.1095/biolreprod.105. 050021

192. Ober RJ, Radu CG, Ghetie V, Ward ES. Differences in promiscuity for antibodyFcRn interactions across species: implications for therapeutic antibodies. Int Immunol (2001) 13(12):1551-9. doi:10.1093/intimm/13.12.1551

193. Petkova SB, Akilesh S, Sproule TJ, Christianson GJ, Al Khabbaz H, Brown AC, et al. Enhanced half-life of genetically engineered human IgG1 antibodies in a humanized FcRn mouse model: potential application in humorally mediated autoimmune disease. Int Immunol (2006) 18(12):1759-69. doi:10.1093/ intimm/dxl110

194. Andersen JT, Foss S, Kenanova VE, Olafsen T, Leikfoss IS, Roopenian DC, et al. Anti-carcinoembryonic antigen single-chain variable fragment antibody variants bind mouse and human neonatal $\mathrm{Fc}$ receptor with different affinities that reveal distinct cross-species differences in serum half-life. J Biol Chem (2012) 287(27):22927-37. doi:10.1074/jbc.m112.355131

195. Frödin J, Lefvert A, Mellstedt H. Pharmacokinetics of the mouse monoclonal antibody 17-1A in cancer patients receiving various treatment schedules. Cancer Res (1990) 50(16):4866-71.

196. Saleh MN, Khazaeli MB, Wheeler RH, Dropcho E, Liu T. Phase I trial of the murine monoclonal anti-GD2 antibody 14G2a in metastatic melanoma. Cancer Res (1992) 52:4342-7.

197. Proetzel G, Roopenian DC. Humanized FcRn mouse models for evaluating pharmacokinetics of human IgG antibodies. Methods (2014) 65(1):148-53. doi:10.1016/j.ymeth.2013.07.005

198. Roopenian DC, Christianson GJ, Sproule TJ. Human FcRn transgenic mice for pharmacokinetic evaluation of therapeutic antibodies. Methods Mol Biol (2010) 602:93-104. doi:10.1007/978-1-60761-058-8_6

199. Andersen JT, Cameron J, Plumridge A, Evans L, Sleep D, Sandlie I. Singlechain variable fragment albumin fusions bind the neonatal $\mathrm{Fc}$ receptor $(\mathrm{FcRn})$ in a species-dependent manner: implications for in vivo half-life evaluation of albumin fusion therapeutics. J Biol Chem (2013) 288(33):24277-85. doi:10.1074/jbc.m113.463000

200. Holt LJ, Basran A, Jones K, Chorlton J, Jespers LS, Brewis ND, et al. Anti-serum albumin domain antibodies for extending the half-lives of short lived drugs. Protein Eng Des Sel (2008) 21(5):283-8. doi:10.1093/protein/gzm067

201. Dall'Acqua WF, Kiener PA, Wu H. Properties of human IgG1s engineered for enhanced binding to the neonatal Fc receptor (FcRn). J Biol Chem (2006) 281(33):23514-24. doi:10.1074/jbc.M604292200

202. Ghetie V, Popov S, Borvak J, Radu C, Matesoi D, Medesan C, et al. Increasing the serum persistence of an IgG fragment by random mutagenesis. Nat Biotechnol (1997) 15(7):637-40. doi:10.1038/nbt0797-637

203. Hinton PR, Johlfs MG, Xiong JM, Hanestad K, Ong KC, Bullock C, et al. Engineered human IgG antibodies with longer serum half-lives in primates. J Biol Chem (2004) 279(8):6213-6. doi:10.1074/jbc.C300470200

204. Hinton PR, Xiong JM, Johlfs MG, Tang MT, Keller S, Tsurushita N. An engineered human IgG1 antibody with longer serum half-life. J Immunol (2006) 176(1):346-56. doi:10.4049/jimmunol.176.1.346

205. Mi W, Wanjie S, Lo S-TT, Gan Z, Pickl-Herk B, Ober RJ, et al. Targeting the neonatal $\mathrm{fc}$ receptor for antigen delivery using engineered $\mathrm{fc}_{\mathrm{c}}$ fragments. J Immunol (2008) 181(11):7550-61. doi:10.4049/jimmunol.181.11.7550

206. Zalevsky J, Chamberlain AK, Horton HM, Karki S, Leung IW, Sproule TJ, et al. Enhanced antibody half-life improves in vivo activity. Nat Biotechnol (2010) 28(2):157-9. doi:10.1038/nbt.1601

207. Ducharme E, Weinberg JM. Etanercept. Expert Opin Biol Ther (2008) 8(4):491-502. doi:10.1517/14712598.8.4.491

208. Suzuki T, Ishii-Watabe A, Tada M, Kobayashi T, Kanayasu-Toyoda T, Kawanishi $\mathrm{T}$, et al. Importance of neonatal FcR in regulating the serum half-life of therapeutic proteins containing the $\mathrm{Fc}$ domain of human IgG1: a comparative study of the affinity of monoclonal antibodies and Fc-fusion proteins to human neonatal FcR. J Immunol (2010) 184(4):1968-76. doi:10.4049/ jimmunol.0903296

209. Syed S, Schuyler PD, Kulczycky M, Sheffield WP. Potent antithrombin activity and delayed clearance from the circulation characterize recombinant hirudin genetically fused to albumin. Blood (1997) 89(9):3243-52.

210. Yeh C, Altaf SA, Hoag SW. Theory of force transducer design optimization for die wall stress measurement during tablet compaction: optimization and validation of split-web die using finite element analysis. Pharm Res (1997) 14(9):1161-70. doi:10.1023/A:1012194504982

211. Duttaroy A, Kanakaraj P, Osborn BL, Schneider H, Pickeral OK, Chen C, et al. Development of a long-acting insulin analog using albumin fusion technology. Diabetes (2005) 54(1):251-8. doi:10.2337/diabetes.54.1.251

212. Osborn BL, Sekut L, Corcoran M, Poortman C, Sturm B, Chen G, et al. Albutropin: a growth hormone-albumin fusion with improved pharmacokinetics and pharmacodynamics in rats and monkeys. Eur J Immunol (2002) 456(1-3):149-58. doi:10.1016/S0014-2999(02)02644-4

213. Halpern W, Riccobene TA, Agostini H, Baker K, Stolow D, Gu M-LL, et al. Albugranin, a recombinant human granulocyte colony stimulating factor (GCSF) genetically fused to recombinant human albumin induces prolonged myelopoietic effects in mice and monkeys. Pharm Res (2002) 19(11):1720-9. doi:10.1023/A:1020917732218

214. Bain VG, Kaita KD, Yoshida EM, Swain MG, Heathcote EJ, Neumann AU, et al. A phase 2 study to evaluate the antiviral activity, safety, and pharmacokinetics 
of recombinant human albumin-interferon alfa fusion protein in genotype 1 chronic hepatitis C patients. J Hepatol (2006) 44(4):671-8. doi:10.1016/j.jhep. 2005.12.011

215. Subramanian GM, Fiscella M, Lamousé-Smith A, Zeuzem S, McHutchison JG. Albinterferon alpha-2b: a genetic fusion protein for the treatment of chronic hepatitis C. Nat Biotechnol (2007) 25(12):1411-9. doi:10.1038/nbt1364

216. Sung C, Nardelli B, LaFleur DW, Blatter E, Corcoran M, Olsen HS, et al. An IFN-beta-albumin fusion protein that displays improved pharmacokinetic and pharmacodynamic properties in nonhuman primates. J Immunol (2003) 23(1):25-36. doi:10.1089/10799900360520423

217. McDonagh CF, Huhalov A, Harms BD, Adams S. Antitumor activity of a novel bispecific antibody that targets the ErbB2/ErbB3 oncogenic unit and inhibits heregulin-induced activation of ErbB3. Mol Cancer Ther (2012) 11:582-93. doi:10.1158/1535-7163.MCT-11-0820

218. Evans L, Hughes M, Waters J, Cameron J. The production, characterisation and enhanced pharmacokinetics of scFv-albumin fusions expressed in Saccharomyces cerevisiae. Protein Expr Purif (2010) 73(2):113-24. doi:10.1016/j. pep.2010.05.009

219. Yazaki PJ, Kassa T, Cheung C, Crow DM. Biodistribution and tumor imaging of an anti-CEA single-chain antibody-albumin fusion protein. Nucl Med Biol (2008) 35(2):151-8. doi:10.1016/j.nucmedbio.2007.10.010

220. Müller D, Karle A, Meißburger B, Höfig I, Stork R, Kontermann RE. Improved pharmacokinetics of recombinant bispecific antibody molecules by fusion to human serum albumin. J Biol Chem (2007) 282(17):12650-60. doi:10.1074/ jbc.M700820200

221. Smith BJ, Popplewell A, Athwal D, Chapman AP, Heywood S, West SM, et al. Prolonged in vivo residence times of antibody fragments associated with albumin. Bioconjug Chem (2001) 12(5):750-6. doi:10.1021/bc010003g

222. Schulte S. Use of albumin fusion technology to prolong the half-life of recombinant factor VIIa. Thromb Res (2008) 122(Suppl 4):9. doi:10.1016/S00493848(08)70029-X

223. Herzog E, Harris S, McEwen A, Henson C, Pragst I, Dickneite G, et al. Recombinant fusion protein linking factor VIIa with albumin (rVIIa-FP): tissue distribution in rats. Thromb Res (2014) 134(2):495-502. doi:10.1016/j.thromres 2014.05.031

224. Weimer T, Wormsbächer W, Kronthaler U, Lang W, Liebing U, Schulte S. Prolonged in-vivo half-life of factor VIIa by fusion to albumin. Thromb Haemost (2008) 99(4):659-67. doi:10.1160/TH07-08-0525

225. Golor G, Bensen-Kennedy D, Haffner S, Easton R, Jung K, Moises T, et al. Safety and pharmacokinetics of a recombinant fusion protein linking coagulation factor VIIa with albumin in healthy volunteers. J Thromb Haemost (2013) 11(11):1977-85. doi:10.1111/jth.12409

226. Poole RM, Nowlan ML. Albiglutide: first global approval. Drugs (2014) 74(8):929-38. doi:10.1007/s40265-014-0228-2

227. Baggio LL, Huang Q, Brown TJ, Drucker DJ. A recombinant human glucagonlike peptide (GLP)-1-albumin protein (albugon) mimics peptidergic activation of GLP-1 receptor-dependent pathways coupled with satiety, gastrointestinal motility, and glucose homeostasis. Diabetes (2004) 53(9):2492-500. doi:10.2337/diabetes.53.9.2492

228. Kratz F, Abu Ajaj K, Warnecke A. Anticancer carrier-linked prodrugs in clinical trials. Expert Opin Investig Drugs (2007) 16(7):1037-58. doi:10.1517/13543784. 16.7.1037

229. Bolling C, Graefe T, Lübbing C, Jankevicius F, Uktveris S, Cesas A, et al. Phase II study of MTX-HSA in combination with cisplatin as first line treatment in patients with advanced or metastatic transitional cell carcinoma. Invest New Drugs (2006) 24(6):521-7. doi:10.1007/s10637-006-8221-6

230. Wunder A, Müller-Ladner U, Stelzer EH, Funk J, Neumann E, Stehle G, et al. Albumin-based drug delivery as novel therapeutic approach for rheumatoid arthritis. J Immunol (2003) 170(9):4793-801. doi:10.4049/jimmunol.170.9. 4793

231. Stehle G, Wunder A, Sinn H, Schrenk HH, Schütt S, Frei E, et al. Pharmacokinetics of methotrexate-albumin conjugates in tumor-bearing rats. Anticancer Drugs (1997) 8(9):835-44. doi:10.1097/00001813-199708000-00006

232. Miele E, Spinelli GP, Miele E, Tomao F, Tomao S. Albumin-bound formulation of paclitaxel (Abraxane ABI-007) in the treatment of breast cancer. Int Immunol (2009) 4:99-105. doi:10.2147/IJN.S3061

233. Petrelli F, Borgonovo K, Barni S. Targeted delivery for breast cancer therapy: the history of nanoparticle-albumin-bound paclitaxel. Expert Opin Pharmacother (2010) 11(8):1413-32. doi:10.1517/14656561003796562
234. Hersh EM, O’Day SJ, Ribas A, Samlowski WE. A phase 2 clinical trial of nabpaclitaxel in previously treated and chemotherapy-naive patients with metastatic melanoma. Cancer (2010) 116(1):155-63. doi:10.1002/cncr.24720

235. Kottschade LA, Suman VJ, Amatruda T. A phase II trial of nab-paclitaxel (ABI$007)$ and carboplatin in patients with unresectable stage IV melanoma. Cancer (2011) 117(8):1704-10. doi:10.1002/cncr.25659

236. Kottschade LA, Suman VJ, Perez DG, McWilliams RR. A randomized phase 2 study of temozolomide and bevacizumab or nab-paclitaxel, carboplatin, and bevacizumab in patients with unresectable Stage IV melanoma. Cancer (2013) 119(3):586-92. doi:10.1002/cncr.27760

237. Kratz F, Müller-Driver R, Hofmann I. A novel macromolecular prodrug concept exploiting endogenous serum albumin as a drug carrier for cancer chemotherapy. J Med Chem (2000) 43(7):1253-6. doi:10.1021/jm9905864

238. Baggio LL, Huang Q, Cao X, Drucker DJ. An albumin-exendin-4 conjugate engages central and peripheral circuits regulating murine energy and glucose homeostasis. Gastroenterology (2008) 134(4):1137-47. doi:10. 1053/j.gastro.2008.01.017

239. Kim JG, Baggio LL, Bridon DP, Castaigne JP, Robitaille MF, Jette L, et al. Development and characterization of a glucagon-like peptide 1-albumin conjugate: the ability to activate the glucagon-like peptide 1 receptor in vivo. Diabetes (2003) 52(3):751-9. doi:10.2337/diabetes.52.3.751

240. Léger R, Thibaudeau K, Robitaille M, Quraishi O, van Wyk P, Bousquet-Gagnon $\mathrm{N}$, et al. Identification of CJC-1131-albumin bioconjugate as a stable and bioactive GLP-1(7-36) analog. Bioorg Med Chem Lett (2004) 14(17):4395-8. doi:10.1016/j.bmcl.2004.06.066

241. Giannoukakis N. CJC-1131. ConjuChem. Curr Opin Investig Drugs (2003) 4(10):1245-9.

242. Simon M, Frey R, Zangemeister-Wittke U, Plückthun A. Orthogonal assembly of a designed ankyrin repeat protein-cytotoxin conjugate with a clickable serum albumin module for half-life extension. Bioconjug Chem (2013) 24(11):1955-66. doi:10.1021/bc4004102

243. Klein O, Lynge J, Endahl L, Damholt B, Nosek L, Heise T. Albumin-bound basal insulin analogues (insulin detemir and NN344): comparable time-action profiles but less variability than insulin glargine in type 2 diabetes. Diabetes Obes Metab (2007) 9(3):290-9. doi:10.1111/j.14631326.2006.00685.x

244. Koehler MF, Zobel K, Beresini MH, Caris LD, Combs D, Paasch BD, et al. Albumin affinity tags increase peptide half-life in vivo. Bioorg Med Chem Lett (2002) 12(20):2883-6. doi:10.1016/S0960-894X(02)00610-8

245. Zobel K, Koehler MF, Beresini MH, Caris LD, Combs D. Phosphate ester serum albumin affinity tags greatly improve peptide half-life in vivo. Bioorg Med Chem Lett (2003) 13(9):1513-5. doi:10.1016/S0960-894X(03)00209-9

246. Hermansen K, Davies M, Derezinski T, Martinez Ravn G, Clauson P, Home P. A 26-week, randomized, parallel, treat-to-target trial comparing insulin detemir with NPH insulin as add-on therapy to oral glucose-lowering drugs in insulin-naive people with type 2 diabetes. Diabetes Care (2006) 29(6):1269-74. doi: $10.2337 / \mathrm{dc} 05-1365$

247. Home P, Kurtzhals P. Insulin detemir: from concept to clinical experience. Expert Opin Pharmacother (2006) 7(3):325-43. doi:10.1517/ 14656566.7.3.325

248. Rendell M. Insulin degludec: a long-acting modern insulin analogue with a predictable pharmacokinetic/pharmacodynamic profile. Drugs Today (2013) 49(6):387-97. doi:10.1358/dot.2013.49.6.1976051

249. Agerso H, Jensen LB, Elbrond B, Rolan P, Zdravkovic M. The pharmacokinetics, pharmacodynamics, safety and tolerability of NN2211, a new longacting GLP-1 derivative, in healthy men. Diabetologia (2002) 45(2):195-202. doi:10.1007/s00125-001-0719-z

250. Trüssel S, Dumelin C, Frey K, Villa A, Buller F, Neri D. New strategy for the extension of the serum half-life of antibody fragments. Bioconjug Chem (2009) 20(12):2286-92. doi:10.1021/bc9002772

251. Walker A, Dunlevy G, Rycroft D, Topley P, Holt LJ, Herbert T, et al. Antiserum albumin domain antibodies in the development of highly potent, efficacious and long-acting interferon. Protein Eng Des Sel (2010) 23(4):271-8. doi:10.1093/protein/gzp091

252. Tijink BM, Laeremans T, Budde M, Stigter-van Walsum M, Dreier T, de Haard $\mathrm{HJ}$, et al. Improved tumor targeting of anti-epidermal growth factor receptor Nanobodies through albumin binding: taking advantage of modular Nanobody technology. Mol Cancer Ther (2008) 7(8):2288-97. doi:10.1158/1535-7163. MCT-07-2384 
253. Dennis MS, Zhang M, Meng YG, Kadkhodayan M, Kirchhofer D, Combs D, et al. Albumin binding as a general strategy for improving the pharmacokinetics of proteins. J Biol Chem (2002) 277(38):35035-43. doi:10.1074/jbc. M205854200

254. Nguyen A, Reyes AE, Zhang M, McDonald P, Wong WL, Damico LA, et al. The pharmacokinetics of an albumin-binding Fab (AB.Fab) can be modulated as a function of affinity for albumin. Protein Eng Des Sel (2006) 19(7):291-7. doi:10.1093/protein/gzl011

255. Dennis MS, Jin H, Dugger D, Yang R, McFarland L, Ogasawara A, et al. Imaging tumors with an albumin-binding Fab, a novel tumor-targeting agent. Cancer Res (2007) 67(1):254-61. doi:10.1158/0008-5472.CAN-06-2531

256. Schlapschy M, Theobald I, Mack H, Schottelius M, Wester H-JJ, Skerra A. Fusion of a recombinant antibody fragment with a homo-amino-acid polymer: effects on biophysical properties and prolonged plasma half-life. Protein Eng Des Sel (2007) 20(6):273-84. doi:10.1093/protein/gzm020

257. Nord K, Gunneriusson E, Ringdahl J, Ståhl S, Uhlén M, Nygren PA. Binding proteins selected from combinatorial libraries of an alpha-helical bacterial receptor domain. Nat Biotechnol (1997) 15(8):772-7. doi:10.1038/nbt0897-772

258. Tolmachev V, Orlova A, Pehrson R, Galli J, Baastrup B, Andersson K, et al. Radionuclide therapy of HER2-positive microxenografts using a $177 \mathrm{Lu}$ labeled HER2-specific Affibody molecule. Cancer Res (2007) 67(6):2773-82. doi:10.1158/0008-5472.CAN-06-1630
259. Andersen JT, Pehrson R, Tolmachev V, Daba MB, Abrahmsén L, Ekblad C. Extending half-life by indirect targeting of the neonatal $F_{c}$ receptor ( $\left.F c R n\right)$ using a minimal albumin binding domain. J Biol Chem (2011) 286(7):5234-41. doi:10.1074/jbc.m110.164848

Conflict of Interest Statement: The authors declare that the research was conducted in the absence of any commercial or financial relationships that could be construed as a potential conflict of interest.

Received: 24 September 2014; accepted: 17 December 2014; published online: 26 January 2015.

Citation: Sand KMK, Bern M, Nilsen J, Noordzij HT, Sandlie I and Andersen JT (2015) Unraveling the interaction between FcRn and albumin: opportunities for design of albumin-based therapeutics. Front. Immunol. 5:682. doi: 10.3389/fimmu.2014.00682 This article was submitted to Immunotherapies and Vaccines, a section of the journal Frontiers in Immunology.

Copyright (C) 2015 Sand, Bern, Nilsen, Noordzij, Sandlie and Andersen. This is an open-access article distributed under the terms of the Creative Commons Attribution License (CC BY). The use, distribution or reproduction in other forums is permitted, provided the original author(s) or licensor are credited and that the original publication in this journal is cited, in accordance with accepted academic practice. No use, distribution or reproduction is permitted which does not comply with these terms. 